Revista IBERC

v. 5 , n. 1 , p. $78-111$, jan./abr. 2022

www.responsabilidadecivil.org/revista-iberc

DOI: https://doi.org/10.37963/iberc.v3i2.201

\title{
A RESPONSABILIDADE CIVIL DO EMPREGADOR NOS CASOS DE AGRESSÃO FÍSICA SOFRIDA PELO TRABALHADOR
}

\author{
THE CIVIL LIABILITY OF THE EMPLOYER IN CASES OF PHYSICAL AGGRESSION \\ SUFFERED BY THE WORKER
}

\author{
André Araújo Molina
}

\begin{abstract}
RESUMO: O artigo investiga a responsabilidade civil do empregador pelo danos resultantes das agressões físicas sofridas pelos trabalhadores, tanto quando o ato lesivo tenha sido praticado por um colega de trabalho, quanto por parte de terceiros, estranhos à relação contratual, com especial atenção à diferenciação do enquadramento previdenciário e civil do evento, bem como apontando as diferenças de tratamento jurídico nas atividades em que o risco de agressão física é inerente aos riscos próprios da atividade, atraindo a responsabilidade civil objetiva.
\end{abstract}

Palavras-chave: responsabilidade civil; agressão física; direito do trabalho; enquadramento jurídico; riscos da atividade.

\begin{abstract}
The paper investigates the employer's civil liability for damages resulting from physical aggressions suffered by workers, both when the harmful act was committed by a coworker, or by third parties, outside the contractual relationship, with special attention to the differentiation of the framework social security and civil of the event, as well as pointing out the differences in legal treatment in activities in which the risk of physical aggression is inherent to the activity's own risks, attracting objective civil responsibility.
\end{abstract}

Keywords: civil liability; physical aggression; labor law; legal framework; activity risks.

SUMÁRIO: Introdução. 1. Múltiplas consequências jurídicas dos acidentes de trabalho. 2. Enquadramento previdenciário da agressão física. 3. Responsabilidade civil. 3.1. Excludentes de nexo causal. 4. Agressão por terceiros estranhos à relação contratual. 5. Agressão por colega de trabalho. 6. Revisão da jurisprudência do Tribunal Superior do Trabalho. 7. Conclusões. Referências.

\section{INTRODUÇÃO}

$\mathrm{O}$ art. $7^{\circ}, \mathrm{XXVIII}$, da Constituição de 1988 consagrou no ordenamento brasileiro a possibilidade de incidir a dupla proteção do trabalhador vítima de acidente de trabalho, sendo amparado tanto pela cobertura previdenciária, a cargo do INSS, quanto pelas indenizações de responsabilidade civil, a que está obrigado o empregador quando incorrer em dolo ou culpa,

\footnotetext{
i Pós-Doutor em Direito do Trabalho pela USP, Doutor em Filosofia do Direito pela PUC/SP, Mestre em Direito do Trabalho pela PUC/SP, Bacharel em Direito pela UFMT, Titular da Academia Brasileira de Direito do Trabalho (ABDT), Titular da Academia Mato-Grossense de Direito (AMD), Titular do Instituto Brasileiro de Estudos em Responsabilidade Civil (IBERC) e Juiz do Trabalho Titular no TRT da $23^{\text {a }}$ Região (Mato Grosso). E-mail: aamolina@bol.com.br / ORCID: http://orcid.org/0000-0003-1345-5410
} 
inclusive tendo o Supremo Tribunal Federal sufragado a interpretação evolutiva em torno da possibilidade da responsabilização civil objetiva em determinadas hipóteses ${ }^{1}$.

Na perspectiva processual, o art. 114, I, da Constituição Federal, quando fixou a competência trabalhista para as ações oriundas da relação de trabalho, deixou à cargo da Justiça Especializada, também, a apreciação, incidental, da ocorrência de um acidente de trabalho previdenciário, quando for julgar as possíveis consequências contratuais do sinistro, como a suspensão do contrato de trabalho, o recolhimento do FGTS do período da licença, a garantia provisória de emprego após a alta previdenciária etc. ${ }^{2}$

O mesmo art. 114, VI, desde a redação dada pela EC n. 45 de 2004, atribuiu à Justiça do Trabalho a competência material para o julgamento das demandas de responsabilidade civil decorrentes da relação de trabalho, inserindo-se aquelas originadas de um acidente de trabalho ${ }^{3}$, inclusive as ajuizadas pelos sucessores do trabalhador, eventualmente, falecido, no acidente ${ }^{45}$.

Dentro desse quadro constitucional, nas hipóteses fáticas em que um trabalhador é agredido fisicamente no exercício da sua atividade, poderá ser caracterizado um acidente de trabalho previdenciário, para fins protetivos pela autarquia, bem como precipitar as ações na Justiça do Trabalho, tanto para o reconhecimento incidental do acidente previdenciário, com o objetivo de buscar os reflexos no contrato, quanto para fazer pedidos de responsabilização civil do empregador, podendo, inclusive, cumular as demandas na mesma petição inicial.

Para o adequado enfrentamento dessas ações é indispensável a compreensão das distintas esferas de proteção jurídica que incidem sobre o mesmo fato do acidente, decorrendo a urgente necessidade da delimitação dos seus distintos requisitos, para então o juiz aplicar, isolada ou cumulativamente, as múltiplas consequências jurídicas existentes, zelando para não confundir os sistemas, o que acabaria levando ao sincretismo metodológico equivocado, com consequências desastrosas, como de resto ainda faz grande parte da doutrina especializada e boa quantidade dos julgados do Tribunal Superior do Trabalho.

\footnotetext{
1 "O artigo 927, parágrafo único, do Código Civil é compatível com artigo $7^{\circ}$, inciso XXVIII da Constituição Federal, sendo constitucional a responsabilização objetiva do empregador por danos decorrentes de acidentes de trabalho nos casos especificados em lei ou quando a atividade normalmente desenvolvida por sua natureza apresentar exposição habitual a risco especial, com potencialidade lesiva e implicar ao trabalhador ônus maior do que aos demais membros da coletividade." (STF - Plenário - RE n. 828.040 Repercussão Geral - Rel. Min. Alexandre de Moraes - DJE 26.06.2020).

2 Ressalve-se que a competência material para o julgamento das ações ajuizadas pelos seguradostrabalhadores em face do INSS, para a caracterização de um acidente de trabalho previdenciário, com o objetivo de recebimento dos benefícios previdenciários, é da Justiça Comum Estadual (art. 109, I, e $\S 2^{\circ}$, da Constituição Federal).

3 "A Justiça do Trabalho é competente para processar e julgar as ações de indenização por danos morais e patrimoniais decorrentes de acidente de trabalho propostas por empregado contra empregador, inclusive aquelas que ainda não possuíam sentença de mérito em primeiro grau quando da promulgação da EC 45/2004." (Súmula Vinculante n. 22 do STF).

${ }^{4}$ STF - Plenário - RE n. 600.091 - Repercussão Geral - Rel. Min. Dias Toffoli - DJE 15.08.2011.

5 "Nos termos do art. 114, inc. VI, da Constituição da República, a Justiça do Trabalho é competente para processar e julgar ações de indenização por dano moral e material, decorrentes da relação de trabalho, inclusive as oriundas de acidente de trabalho e doenças a ele equiparadas, ainda que propostas pelos dependentes ou sucessores do trabalhador falecido" (Súmula n. 392 do TST).
} 
Assim, diante da constatação dos equívocos que ainda são cometidos, justifica-se a presente pesquisa acadêmica, de modo que são seus objetivos extremar, a partir dos conceitos fundamentais da teoria geral do direito, o múltiplo enquadramento do fato único e as respectivas consequências jurídicas, tanto quando a agressão é praticada por um colega de trabalho, quanto por um terceiro, sem relação com o contrato de trabalho, ao final culminando o artigo com a revisão crítica da jurisprudência do Tribunal Superior do Trabalho, com o propósito de fomentar a reflexão e despertar o interesse pela revisão do senso comum.

\section{MÚLTIPLAS CONSEQUÊNCIAS JURÍDICAS DOS ACIDENTES DE TRABALHO}

O fato social do acidente de trabalho foi considerado relevante pelo legislador em diversos momentos, resultando na sua captura em diferentes esferas jurídicas, convertendo-o em fato jurídico, na medida em que as legislações, paulatinamente, resolveram utilizá-lo como hipótese fática para a imputação de diferentes consequências, no direito trabalhista, tributário, previdenciário, securitário, penal, administrativo e civil.

Dito de outro modo, o fato único, quando eleito e positivado pelo legislador, dará origem a diversos elementos (dispositivos ou textos normativos) do ordenamento jurídico. Em cada um desses ramos jurídicos a idêntica hipótese fática será integrante de normas jurídicas diferentes, com a prescrição de condutas variadas, cujas violações ensejarão as consequências jurídicas também diversas, instaurando-se tantas relações jurídicas quantas forem as previsões legislativas ${ }^{6}$, tendo, com efeito, multifacetados sujeitos-de-direito em seus polos.

Segue que o acidente de um trabalhador é fato jurídico que implica consequências jurídicas I) trabalhistas (suspensão ou extinção do contrato de trabalho, recolhimento do FGTS, garantia provisória de emprego, pagamento das verbas rescisórias etc.), II) previdenciárias (pagamento do benefício ao segurado ou seus dependentes etc.), III) civis (responsabilidade do empregador), IV) tributárias (alteração da alíquota do SAT), V) administrativas (lavraturas de autos de infração, caso alguma obrigação quanto à segurança e medicina do trabalho tenha sido violada), VI) penais (crimes de lesões corporais ou homicídio culposo, p. ex.), sem falar da possibilidade da VII) relação securitária, caso o empregador tenha contratado seguro privado em benefício dos trabalhadores a ele vinculados.

O enquadramento (incidência) e as respectivas consequências jurídicas diferentes que decorrem do mesmo fato (acidente) são moldados pelo legislador em veículos legislativos distintos, como a Constituição, a CLT, a Lei n. 8.213/1991, o Código Civil, o Código Penal, a

\footnotetext{
6 "As normas jurídicas projetam-se como feixes luminosos sobre a experiência social: e só enquanto as relações sociais passam sob a ação desse facho normativo, é que elas adquirem a significado de 'relações jurídicas'. (...) Quando uma relação de homem para homem se subsume ao modelo normativo instaurado pelo legislador, essa realidade concreta é reconhecida como sendo relação jurídica." (REALE, Miguel. Lições preliminares de direito. 27 ed. São Paulo: Saraiva, 2007, p. 215-216).
} 
legislação extravagante etc., cada uma com requisitos diferentes, nada obstante a hipótese fática seja sempre a mesma: a verificação de um acidente de trabalho.

Revela-se, evidente, que não são os mesmos os requisitos para o reconhecimento das consequências jurídicas para as esferas civil, trabalhista ou criminal, p. ex. É o Código Civil, a CLT e o Código Penal, respectivamente, quem dirão os pressupostos para a instauração dessas distintas relações jurídicas e a imputação das suas especiais consequências, podendo, conforme o caso, atendê-los, isolada ou cumulativamente, o que geraria a imposição das consequências de uma única esfera ou de várias delas, respectivamente.

Isso significa que é absolutamente possível que um mesmo fato seja acidente de trabalho para fins previdenciários, porém não atenda os pressupostos para a responsabilidade civil, não gerando nenhuma consequência nessa última esfera jurídica.

Logo, não há que se confundir o conceito de acidente de trabalho previdenciário, previsto nos arts. 19, 20 e 21 da Lei n. 8.213/1991, com as hipóteses dos eventos que geram a responsabilidade civil, cujos requisitos são diversos, dispostos na Constituição Federal, no Código Civil ou nos diversos microssistemas de responsabilização ${ }^{7}$.

Pontes de Miranda já advertia, em sua clássica lição de teoria geral do direito, que "Temos, porém, no trato do direito, de discernir o mundo jurídico e o que, no mundo, não é mundo jurídico. Por falta de atenção aos dois mundos muitos erros se cometem e, o que é mais grave, se priva a inteligência humana de entender, intuir e dominar o direito."8

É comum chegar ao Judiciário Trabalhista ações em que há cumulação objetiva de pedidos a partir de um acidente sofrido pelo trabalhador, trazendo tanto demandas relacionadas aos efeitos previdenciários no contrato (FGTS do período do afastamento e reintegração diante da garantia provisória de emprego), quanto as indenizações de responsabilidade civil (danos patrimoniais e pessoais), ocasião em que o julgador deverá saber dar o correto tratamento - já que, geralmente, as petições iniciais baralham as esferas -, avaliando a primeira parte a partir da incidência da Lei n. 8.213/1991 e a segunda já com apoio nos requisitos específicos da responsabilidade civil, do Código Civil, sendo natural que, desse mesmo fato (acidente), ocorra acolhimento dos pedidos em um capítulo e a rejeição no outro, sem nenhuma perplexidade ou contradição na decisão.

Um singelo exemplo encontra-se no art. 21, IV, "d", da Lei n. 8.213/1991, que considera, para fins previdenciários, o acidente de percurso como equiparado ao acidente de trabalho, inclusive quando o trabalhador se desloca com o seu veículo próprio. Seria a hipótese em que o trabalhador, dirigindo seu carro, para no sinal vermelho no caminho para o trabalho, quando é

\footnotetext{
${ }^{7}$ MOLINA, André Araújo. Sistemas de responsabilidade civil objetiva e os acidentes de trabalho. Revista do TST, São Paulo, vol. 79, n. 2, p. 70/117, abr./jun. 2013.

${ }^{8}$ MIRANDA, Francisco Cavalcante Pontes de. Tratado de Direito Privado. Campinas: Bookseller, Tomo I, 1999, p. 52.
} 
atingido por outro carro que vinha logo atrás e que não conseguiu frear, trazendo como consequência lesões corporais e o afastamento por 60 dias das atividades laborativas.

A legislação específica considera esse evento como um acidente de trabalho para fins de proteção previdenciária - recebimento do auxílio-doença acidentário do INSS -, quando o trabalhador retornaria, após a alta, com a garantia provisória de emprego (art. 118 da Lei n. 8213/1991), porém, por faltar diversos dos pressupostos da responsabilidade civil (ato lesivo do empregador, culpa e nexo causal), não se cogitaria de nenhuma indenização civil devida pela empresa no caso, mas apenas pelo efetivo causador do dano (motorista do outro veículo).

Deveras, a responsabilidade do INSS é da modalidade objetiva e por risco integral, apoiada na solidariedade e no risco social $^{9}$, na medida em que o intento da sua criação foi o de servir como meio de proteção dos trabalhadores nos momentos de incapacidade, temporária ou permanente, independentemente da apuração de culpa do empregador, de terceiro ou mesmo da própria vítima no acidente, já que a sua conduta contributiva não rompe com a obrigação legal da autarquia de ampará-lo.

É pela responsabilidade objetiva por risco integral do INSS, que a Lei n. 8.213/1991 chega ao ponto de considerar como acidente - "para os efeitos desta Lei", sublinhe-se - até os casos de desabamento, inundação, incêndio e outros casos fortuitos ou decorrentes de força maior (art. 21, II, “e”), que são hipóteses clássicas de exclusão de responsabilidade civil.

A partir do mesmo raciocínio, alguém poderá ser, ao mesmo tempo, apto para o direito previdenciário, estando com o contrato ativo e trabalhando (readaptado em nova função), e inválido para a responsabilidade civil (art. 950 do Código Civil - inaptidão para o seu ofício ou profissão originária), hipótese em que haverá condenação do empregador, entre outros, no pagamento da pensão mensal vitalícia a um trabalhador ativo no mercado de trabalho. ${ }^{10}$

Decorre dessa distinção das esferas jurídicas, a quase imprestabilidade, nas ações de responsabilidade civil, do eventual laudo pericial, administrativo ou mesmo judicial, como prova emprestada, elaborado no contexto e para os fins exclusivo da aplicação da legislação

\footnotetext{
${ }^{9}$ Carlos Alberto Pereira de Castro e João Batista Lazzari apontam, entre os fundamentos da Previdência Social, a intervenção do Estado na proteção da dignidade humana, a solidariedade social, a compulsoriedade da filiação, a proteção aos previdentes, a redistribuição de renda e o risco social, acrescentando que "cabe à sociedade assegurar seu sustento ao indivíduo vitimado por uma incapacidade laborativa, já que toda a coletividade deve prestar solidariedade aos desafortunados, sendo tal responsabilidade de cunho objetivo não se cogitando, sequer, da culpa do vitimado." (Manual de direito previdenciário. 23 ed. Rio de Janeiro: Forense, 2020, p. 83).

10 É o caso, p. ex., do atleta profissional do time da Chapecoense, que sobreviveu ao trágico acidente aéreo de novembro de 2016, tendo amputada a sua perna direita, trauma que inviabilizou a continuidade da sua carreira como goleiro profissional, porém não o impediu de continuar ativo no mercado de trabalho, tanto ocupando a função de embaixador do time até o ano de 2021, como permitindo trabalhar em outras atividades, como a música e atividades artísticas em programas televisivos. Por todos: (https://www.metropoles.com/esportes/futebol/quatro-anos-depois-veja-como-estao-6-sobreviventes-doacidente-da-chapecoense).
} 
previdenciária, amparado em seus requisitos especiais, no contexto da responsabilidade por risco integral do órgão previdenciário. ${ }^{11}$

Destarte, quando o objeto do processo envolver apenas os pedidos das indenizações por danos patrimoniais e pessoais, estaremos tratando dos reflexos de responsabilidade civil do acidente, razão pela qual é imprópria a invocação, pela inicial, contestação ou sentença, dos dispositivos da Lei n. 8.213/1991, na medida em que esse arsenal legislativo tem incidência, apenas, na esfera previdenciária, cuidando da relação jurídica entre o segurado-trabalhador e o INSS, mas não tem nenhuma valia jurídica para solucionar as pretensões de responsabilidade civil, sequer para fins de conceituar o acidente, como amiúde ainda ocorre no foro ${ }^{12}$, da mesma forma que o juiz criminal, para apurar as consequências penais de um acidente que resultou na morte do trabalhador, não fará o enquadramento do fato na lei previdenciária, mas no Código Penal (p. ex., homicídio culposo - art. 121, §§ $3^{\circ}$ a $5^{\circ}$ ), para impor a eventual condenação.

São por essas razões que, desde há alguns anos ${ }^{13}$, temos, respeitosamente, divergido da quase totalidade da doutrina especializada em torno do assunto, que mistura os requisitos previdenciários com os da responsabilidade civil ${ }^{14}$, incidindo em um sincretismo metodológico inadequado, acabando, na prática, por impor o dever de indenizar quando o caso era somente de proteção previdenciária, e vice-versa, confusão que terminou influenciando definitivamente os tribunais trabalhistas ${ }^{15}$.

${ }^{11}$ Bem por isso, discordamos da afirmação de José Cairo Júnior, que, na linha da doutrina majoritária, mistura os requisitos e as consequências entre os sistemas previdenciário e civil: "Conclui-se, assim, que se o nexo etiológico da enfermidade do empregado é definido através do NTEP e a empresa não contesta administrativa e/ou judicialmente o laudo do perito do INSS, haverá uma presunção absoluta de que a doença tem relação com o trabalho. Isso implica a produção de efeitos inclusive em relação a eventuais ações trabalhistas promovidas pelo empregado, na qual postule indenização por danos morais e materiais." ( $O$ acidente do trabalho e a responsabilidade civil do empregador. 8 ed. São Paulo: LTr, 2015, p. 171).

12 Exemplificativamente: "A responsabilidade civil geradora do direito à indenização exige, no mínimo, a existência de dois requisitos concomitantes: o dano e o nexo causal. Presentes estes dois requisitos, a verificação da responsabilidade se encaminha então para a avaliação da presença de culpa do agente ou da possibilidade da responsabilidade ser objetiva. Cumpre atentar que a responsabilidade civil subsiste ainda que o labor tenha contribuído como concausa para a incapacitação do trabalhador, nos termos do art. 21, I, da Lei 8.213/91 (Art. 21. Equiparam-se também ao acidente do trabalho, para efeitos desta Lei: I - o acidente ligado ao trabalho que, embora não tenha sido a causa única, haja contribuído diretamente para a morte do segurado, para redução ou perda da sua capacidade para o trabalho, ou produzido lesão que exija atenção médica para a sua recuperação;)." (TST - 1ª Turma - RR n. 179200-02.2008.5.17.0191 - Rel. Min. Hugo Carlos Scheuermann - DEJT 19.10.2018).

${ }^{13}$ MOLINA, André Araújo. O nexo causal nos acidentes de trabalho. Revista $L T r$, São Paulo, ano 76, n. 12, p. 1421-1432, dez. 2012.

14 "O dano causado no assalto a ônibus em relação aos empregados da empresa transportadora assume o contorno de infortúnio, ou melhor, de acidente de trabalho, e como tal será analisado e não como uma simples relação de consumo como ocorre com o transporte de passageiros. (...) Não se discute que o dano causado decorre do trabalho, por isso equivalente ao acidente de trabalho. É como caracteriza e define o art. 19 da Lei $n^{\circ} 8.213 / 91$. Ocorrendo o acidente de trabalho, a indenização pelo dano moral e material dele decorre." (VEIGA, Aloysio Corrêa da. Responsabilidade civil no transporte de passageiros: "assalto a ônibus e excludentes". Revista do TST, Brasília, vol. 79, n. 2, p. 42-52, abr./jun. 2013).

15 "DOENÇA OCUPACIONAL. RESPONSABILIDADE CIVIL DO EMPREGADOR. CONCAUSA. CONFIGURAÇÃO. INDENIZAÇÃO POR DANO MORAL. A legislação previdenciária equipara a doença profissional a acidente do trabalho ainda que o trabalho não foi causa única, mas desde que contribua, diretamente, para o surgimento ou agravamento da lesão, conforme dispõe o art. 21, I, da Lei $n^{\circ}$ 8.213/91. Pontue-se que, para a configuração da concausa, não importa se a doença tem caráter congênito ou degenerativo, bastando que o trabalho em condições inadequadas tenha concorrido para a ocorrência do infortúnio. Nessa esteira, comprovada a existência de nexo de concausalidade entre a moléstia da autora e 
Humberto Theodoro Júnior, logo após a promulgação da Constituição de 1988, já tinha notado que a regra do art. $7^{\circ}, \mathrm{XXVIII,} \mathrm{"além} \mathrm{de} \mathrm{manter} \mathrm{o} \mathrm{regime} \mathrm{de} \mathrm{seguro} \mathrm{previdenciário} \mathrm{para} \mathrm{os}$ acidentes do trabalho, deu um passo final para separar, total e definitivamente, o regime da infortunística do regime de responsabilidade civil", de sorte que as ações quanto à última esfera caíram "totalmente no regime do Código Civil."16

Em defesa da sua prática, os defensores do sincretismo poderiam invocar, em tese, a ideia do diálogo das fontes, desenvolvida por Erick Jayme ${ }^{17}$, que encontrou grande acolhida no Brasil ${ }^{18}$, de sorte a justificar a invocação de ambas as legislações e a aplicação da regra que seja mais protetiva dos direitos humanos casuisticamente.

Entretanto, o pressuposto da tese é a existência de uma antinomia, o atendimento simultâneo do descritor de duas ou mais normas jurídicas, a justificar que o interprete busque um mecanismo para solucioná-la, para identificar a norma aplicável, o que poderá se dar pelos métodos excludentes clássicos da hierarquia, temporalidade ou especialidade ou pela sugestão mais inclusiva de Eric Jayme, de aplicar aquela que for mais benéfica, naquele caso concreto, sem que a decisão importe em revogação da regra afastada para outros casos futuros.

Ocorre que tal raciocínio não tem nenhuma utilidade na questão dos acidentes de trabalho, na medida em que o seu pressuposto (a identificação da antinomia jurídica) não está atendido, pois a Lei n. 8.213/1991 não instaura nenhuma relação jurídica de responsabilidade entre empregados e empregadores, mas apenas entre os segurados e a autarquia previdenciária, não havendo o preenchimento de nenhum descritor da norma jurídica da lei especial, a justificar, em tese, a sua incidência dialogada com os pressupostos de responsabilidade civil previstos no Código Civil.

Não há, com efeito, antinomia que justifique a diálogo normativo, já que a primeira legislação especial previdenciária não tem aplicação para a relação de responsabilidade civil, na medida em que os seus sujeitos-de-direito e pressupostos são bastante diversos.

A rigor, a própria legislação especial diz, expressamente, isto.

o labor, nota-se a responsabilidade civil. Cabível, assim, a indenização, a cargo do empregador. Agravo de instrumento conhecido e desprovido." (TST - 3a Turma - AIRR n. 010084-93.2017.5.03.0151 - Rel. Min. Alberto Luiz Bresciani - DEJT 17.12.2021).

16 THEODORO JÚNIOR, Humberto. A responsabilidade civil na nova Constituição brasileira. Revista Jurídica, Porto Alegre, v. 168, p. 127-137, out. 1991.

17 JAYME, Erik. Identité culturelle et intégration: le droit international privê postmoderne. Recueil des Cours, Académie de Droit Internacional de la Haye, v. 251 (1995), p. 9-267.

18 Cláudia Lima Marques, a partir do período de estudos junto ao professor Erick Jayme na Alemanha, adaptou a teoria do diálogo das fontes para justificar a manutenção do Código de Defesa do Consumidor mesmo após o Código Civil ter regrado hipóteses fáticas idênticas, de modo a que ambos os diplomas sejam, simultaneamente, incidentes, já que há o preenchimento, nos casos concretos, dos pressupostos fáticos de duas ou mais normas. (MARQUES, Cláudia Lima. Superação das antinomias pelo diálogo das fontes: o modelo brasileiro de coexistência entre o Código de Defesa do Consumidor e o Código Civil de 2002. Revista de Direito do Consumidor, São Paulo, vol. 51, p. 34-67, set. 2004). 
O art. 21, caput, da Lei n. 8.213/1991, amiúde invocada para a fundamentação nos casos em que se discute os efeitos de responsabilidade civil dos acidentes de trabalho, vaticina que "Equiparam-se também ao acidente do trabalho, para efeitos desta Lei:" (g.n.).

Também não há espaço para uma alegada aplicação analógica da lei previdenciária na responsabilidade civil, na medida em que não há lacuna - pressuposto para a analogia -, pois a responsabilidade encontra-se, exaustivamente, regrada na Constituição Federal, no Código Civil e na legislação extravagante sobre o tema.

Sebastião Geraldo de Oliveira está entre os respeitáveis autores que defendem que a pretensão judicial de responsabilização civil passa, antecedentemente, pelo enquadramento do fato nos requisitos da legislação previdenciária. Em palavras suas:

\begin{abstract}
A Constituição da República assegura aos trabalhadores, no art. $7^{\circ}, \mathrm{XXVIII,} \mathrm{o}$ direito aos benefícios do seguro contra acidentes do trabalho, sem excluir a indenização a que o empregador está obrigado, quando incorrer em dolo ou culpa. Assim, a postulação judicial das indenizações por danos materiais, morais e/ou estéticos, por parte daquele empregado que foi vítima de acidente ou doença ocupacional, exige, previamente, que o evento danoso esteja enquadrado em uma das hipóteses que a Lei n. 8.213/1991 considera como acidente do trabalho. ${ }^{19}$
\end{abstract}

A adoção da referida linha de compreensão, em nosso sentir, além de transgredir as lições da teoria geral do direito, baralhando os requisitos e as consequências entre os diferentes sistemas jurídicos, na prática acaba por transferir ao empregador uma responsabilidade por risco integral, aos moldes do "seguro universal" previdenciário (art. 201 da Constituição), na medida em que, p. ex., para o direito previdenciário, desde que o trabalho atue, em alguma medida, para o surgimento da doença (concausa - art. 21, I, da Lei n. 8.213/1991), satisfaz-se o INSS e, desde já, autoriza o pagamento do benefício previdenciário pelo seu valor integral, sem a necessidade de investigar a atuação proporcional do trabalho e das demais causas extralaborais na hipótese.

Já para a responsabilidade civil, com vistas a imputar alguma indenização a cargo do empregador no mesmíssimo caso, deverá o juiz avançar para individualizar a participação, efetiva e proporcional, do empregador no surgimento ou agravamento da doença, sendo ele, então, responsável apenas pelos resultados diretos e imediatos decorrentes da sua conduta ou omissão (art. 944 do Código Civil).

Exemplificativamente, o TRT da $23^{a}$ Região julgou um caso em que um motorista alegou o surgimento de doença ocupacional e a incapacidade para o trabalho como decorrência da jornada extenuante e do carregamento e descarregamento do caminhão ${ }^{20}$.

19 OLIVEIRA, Sebastião Geraldo de. Indenizações por acidente do trabalho ou doença ocupacional. 10 ed. São Paulo: LTr, 2018, p. 43.

20 TRT 23a Região - RO n. 0000533-63.2012.5.23.0004 - Rel. Des. Roberto Benatar - DEJT 20.01.2014. 
A prova pericial realizada confirmou uma hérnia interdiscal lombar, respondendo, especificamente, nos quesitos, que o trabalho não contribuiu para o surgimento da hérnia, nem atuou em seu agravamento, mas apenas que, na fase aguda, dirigir caminhões e levantar cargas são condutas contraindicadas, na medida em que contribuíam para a dor, sendo recomendada a transferência do trabalhador para outras funções, poupando-o do sofrimento físico. ${ }^{21}$

Contudo, o acórdão local, apoiando-se na legislação previdenciária e no conceito alargado de concausa para esse ramo jurídico, do art. 21, I, da Lei n. 8.213/1991, misturou as esferas jurídicas incidentes, para reformar a sentença, com fundamento na lei previdenciária, quando condenou os réus nas indenizações próprias da responsabilidade civil, entre as quais a indenização por danos morais, o ressarcimento dos danos emergentes e a fixou uma pensão no equivalente a $100 \%$ da remuneração do motorista, sem que o trabalho tenha atuado como causa do surgimento ou agravamento da doença, tendo a decisão transitado em julgado.

O caso demonstra, claramente, que a invocação da Lei n. 8.213/1991 para julgar as ações de responsabilidade civil poderá levar à condenação nos casos em que era hipótese de somente acidente previdenciário, com consequências junto ao INSS e os reflexos indiretos no contrato (garantia provisória p. ex.), bem como, em outras hipóteses, isentar o empregador da responsabilidade civil, porque não atendidos os requisitos da lei previdenciária ${ }^{22}$, mas cujos pressupostos da responsabilidade civil estariam presentes ${ }^{23}$, prejudicando os trabalhadores.

Gustavo Filipe Barbosa Garcia compreendeu o equívoco desse sincretismo, razão pela qual sublinhou que "para a incidência da responsabilidade civil decorrente de acidente do trabalho (...) o nexo causal exigido é mais restrito do que aquele nexo causal amplo e elástico, previsto na Lei n. 8.213/1991"24, inclusive porque a responsabilidade civil privada não admite a teoria do risco integral, mas que foi adotada pela legislação previdenciária.

Fixadas essas distinções, estamos em condições de concluir o tópico reforçando a lição, que há anos temos defendido, de que não se pode confundir as esferas previdenciária e de responsabilidade civil, na medida em que os objetivos, os requisitos e as consequências são muito diferentes nos citados compartimentos do ordenamento jurídico.

21 "RESPOSTA A QUESITOS FORMULADOS PELO JUÍZO. (...) O agravamento causado (...) ampliou a gravidade do estado de saúde do autor? Em que percentual? Não houve agravamento da hérnia em decorrência da função exercida. $\mathrm{O}$ autor apresentaria tais hérnias independentemente de qualquer função que exercesse. (...) Contudo, na fase aguda, dirigir caminhões e levantar cargas seria contra indicado, pois agravaria a clínica (dor), mas não a evolução, piora ou surgimento da hérnia em si."

22 "ACIDENTE DO TRABALHO - EVENTO TÍPICO - LESÃOO NO $5^{\circ}$ DEDO DA MÃO DIREITA - PERÍCIA AUSÊNCIA DE PERDA ÓSSEA - CAPACIDADE LABORATIVA PRESERVADA - BENEFÍCIO ACIDENTÁRIO - DESCABIMENTO - RECURSO IMPROVIDO. A perícia atestou que o autor não apresenta nenhuma limitação da capacidade laborativa em razão das sequelas que ostenta na mão direita, portanto, de rigor a improcedência do pedido." (TJSP - 17ª Câmara de Direito Público - APL n. 9218876-85.2008.8.26.0000 Rel. Des. Antonio Moliterno - DJ 07.07.2011).

${ }^{23}$ Exemplo de um corte sofrido pelo trabalhador em parte visível do seu corpo, que tenha gerado afastamento do trabalho pelo período de 10 dias, evento que não é considerado para fins previdenciários (não atende o pressuposto temporal do art. 19 da Lei n. 8.213/1991), mas que enseja, p. ex., responsabilidade civil pelos danos estéticos, desde que atendidos os requisitos do Código Civil.

${ }^{24}$ GARCIA, Gustavo Filipe Barbosa. Acidentes de trabalho. 4 ed. São Paulo: Método, 2011, p. 77. 
Logo, dentro do objeto específico deste artigo, a depender dos dados fáticos do caso concreto, a agressão física sofrida pelo trabalhador poderá resultar apenas no enquadramento previdenciário a cargo do INSS, somente na responsabilidade civil do empregador ou, inclusive, simultaneamente, despertar ambas as consequências, estando presentes os seus independentes pressupostos, sem prejuízo de o mesmo evento seguir atendendo as hipóteses fáticas das normas jurídicas das esferas administrativa, penal, trabalhista, tributária e securitária.

\section{ENQUADRAMENTO PREVIDENCIÁRIO DA AGRESSÃO FíSICA}

O art. 19 da Lei n. 8.213/1991 fixa os requisitos para o reconhecimento do acidente de trabalho típico, o art. 20 para as doenças ocupacionais e o art. 21 dita as hipóteses de acidente por equiparação, para os efeitos protetivos estritos da lei previdenciária, ocasiões em que haverá responsabilidade do INSS pela quitação dos benefícios previdenciários adequados ao caso.

Especificamente, o art. 21, II, “a”, "b" e "d", da Lei n. 8.213/1991, considera como acidente de trabalho por equiparação, para efeitos previdenciários, o ato de agressão ou ofensa física intencional praticados por terceiro ou companheiros de trabalho, no local e horário de trabalho, inclusive os cometidos por pessoa privada do uso da razão, desde que o evento traga como consequência lesão corporal ou perturbação funcional que cause a perda ou a redução da capacidade para o trabalho por período superior a 15 dias (art. 19 da Lei n. 8.213/1991), ainda que a ofensa seja praticada nos períodos destinados à refeição, descanso ou outras necessidades fisiológicas, no local do trabalho ou durante este (art. $21, \S 1^{\circ}$, da Lei n. 8.213/1991).

Por exemplo, um agente de aeroporto que é agredido fisicamente por um passageiro contrariado com o cancelamento de um voo, gerando lesões que o incapacitem para o labor pelo período de 90 dias, considera-se acidente de trabalho previdenciário, despertando o pagamento do auxílio-doença acidentário, a obrigação de o empregador recolher o FGTS dos meses do afastamento e, depois da alta previdenciária, o contrato de trabalho será retomado com a vítima desfrutando da garantia provisória de emprego de 12 meses, mesmo que o empregador não tenha nenhuma participação, ativa ou omissiva, no ato inesperado e abrupto da agressão feita pelo cliente enfurecido. ${ }^{25}$

Também é acidente de trabalho previdenciário a agressão física cometida por colega de trabalho, que teve origem em uma discussão entre eles no refeitório da empresa, motivada por razões de ordem pessoal, tendo a vítima sofrido traumas que o incapacitem para o trabalho pelo período de 45 dias, ocasião em que receberá benefício previdenciário do INSS e sentirá os reflexos indiretos no contrato de trabalho, caso em que, p. ex., se for dispensado sem justa causa após o

25 https://g1.globo.com/df/distrito-federal/noticia/2021/09/17/apos-perder-voo-passageiro-agride-e-xingafuncionaria-da-gol-no-aeroporto-de-brasilia.ghtml 
retorno do afastamento, poderá pleitear a sua reintegração, como corolário da garantia provisória de emprego de pelo menos 12 meses.

Lado outro, por não atender o requisito da incapacidade temporária superior a 15 dias, exigido pela lei previdenciária, não será considerado acidente de trabalho a ofensa física grave praticada por um colega de trabalho, por ocasião do trabalho e no exercício da atividade.

$\mathrm{Na}$ medida em que a responsabilidade do INSS é objetiva e por risco integral, sem a possibilidade de excludentes, será acidente de trabalho previdenciário até na hipótese em que um garçom, incomodado com a falta de respeito que um cliente tratava a sua colega, partiu para a agressão física e viu-se envolvido em uma briga generalizada, com danos físicos de parte a parte, incapacitando-o para a atividade pelo período de 60 dias em razão de fratura no braço. ${ }^{26}$

Em quase todos os exemplos, os requisitos da lei previdenciária estão atendidos, razão pela qual haverá um acidente de trabalho em razão das agressões físicas sofridas pelos trabalhadores, praticadas por terceiros ou colegas de trabalho, inclusive no caso em que foi o próprio trabalhador quem participou ativamente das mútuas ofensas, fazendo incidir os efeitos da Lei n. 8.213/1991, sejam os devidos pelo próprio INSS, sejam as consequências indiretas no contrato, como a garantia provisória de emprego de 12 meses.

Naturalmente, que nessas mesmas situações, pelo simples fato de os pressupostos da Lei n. 8.213/1991 serem atendidos, com um acidente de trabalho típico ou por equiparação, não haverá, automaticamente, responsabilidade civil do empregador pelos danos materiais e pessoais sofridos pela vítima, mas somente se os requisitos próprios desta esfera protetiva civil, simultaneamente, também estiverem preenchidos, justamente como no caso do exemplo acima em que não houve enquadramento no conceito acidentário de acidente.

\section{RESPONSABILIDADE CIVIL}

Independente da proteção previdenciária, certo é que, na forma do art. $7^{\circ}, \mathrm{XXVIII}$, da Constituição Federal, também poderá ocorrer a responsabilização do empregador caso sejam preenchidos os requisitos específicos do sistema de responsabilidade civil, cujos pressupostos clássicos são o ato lesivo, a culpa em sentido amplo, o nexo causal e o dano.

O primeiro dos requisitos gerais de responsabilidade civil subjetiva é o ato lesivo ou a conduta do causador do dano, na linha do art. 186 do Código Civil. Referido dispositivo exige a atuação humana (ação ou omissão) que viole direito e cause danos a outrem, quando deve-se investigar sobre a voluntariedade ou a culpa, essa nas modalidades da negligência, imperícia ou imprudência, bem como a antijuridicidade da conduta do ofensor.

26 https://costanorte.com.br/cidades/praiagrande/turista-arremessa-salgado-em-garcom-e-acaba-com-luxaco-no-braco-em-praia-grande-sp-1.330366 
$\mathrm{O}$ art. 187 do Código Civil avança para dar uma definição complementar de ato ou conduta ilícita, como aquela praticada no exercício de um direito, mas que ao assim fazer, o seu titular excede manifestamente os limites impostos pelo seu fim econômico ou social, pela boa-fé objetiva ou pelos bons costumes (abuso de direito).

Na responsabilidade civil por acidente de trabalho dificilmente haverá a modalidade da conduta dolosa, na medida em que, em regra, o empregador nunca quer, intencionalmente, que o trabalhador sofra um infortúnio laboral. Na imensa maioria dos casos o que há é a conduta culposa do empregador ou dos seus prepostos, que normalmente deixam de cumprir as normas de proteção da saúde e segurança do trabalhador, violando o art. 157 da CLT, por omissão.

Fica claro o ato lesivo ou a conduta omissiva quando o empregador não respeita as normas de saúde e segurança no trabalho, como são as normas regulamentadoras do Ministério do Trabalho e Previdência, quando o empregador não orienta os trabalhadores sobre os riscos inerentes às suas funções (art. 157 da CLT), quando não implanta os programas de PCMSO, LTCAT, PGR etc., quando não fornece e fiscaliza o correto uso dos equipamentos de proteção individuais e coletivos próprios aos riscos daquela função.

Já a culpa em sentido amplo, englobando a culpa e o dolo, podendo ser conceituada como a consciente e intencional conduta do agente que pratica um ato que acaba causando um dano à vítima. Na culpa, a conduta é consciente, mas o resultado é involuntário, decorrendo da falta de cautela, atenção ou cuidado do agente, tecnicamente conceituada como imprudência, negligência ou imperícia.

Especificamente, em relação aos acidentes de trabalho, a prova da conduta culposa do empregador também é configurada com a violação do art. 157 da CLT, que determina que incumbe às empresas, entre outras obrigações, cumprir e fazer cumprir as normas de proteção do trabalhador e instruir os empregados quanto às precauções que devem tomar no sentido de evitar acidentes.

Quando o empregador descumpre as normas regulamentadoras (NR's), quando não realiza o treinamento adequado, quando não fornece e fiscaliza o uso correto dos equipamentos de proteção individual, estará violando o art. 157 da CLT e, por isso, agindo com culpa (negligência), caso o trabalhador venha a sofrer um acidente, atraindo a sua responsabilidade civil pelo dever de indenizar, desde que atendidos os demais requisitos.

Também para que haja dever de indenizar do empregador deverá haver dano, que pode ser conceituado como a lesão do conjunto de direitos e bens de que é titular uma pessoa, ofendendo interesses juridicamente protegidos. $O$ ataque repercute sobre a vítima podendo atingir os seus interesses patrimoniais e/ou extrapatrimoniais.

$\mathrm{Na}$ experiência nacional, as repercussões patrimoniais são conhecidas como danos materiais e as extrapatrimoniais, inicialmente, como os danos morais. Essa experiência foi recolhida pela Constituição Federal de 1988, no art. $5^{\circ}$, V e X, e, mais recentemente, no art. 186 
do Código Civil, onde o legislador utiliza as expressões danos materiais e danos morais como representativos dos dois grandes gêneros dos danos.

Especificamente no artigo $5^{\circ}, \mathrm{V}$, da Constituição, o constituinte acrescenta os danos à imagem, o que levou a doutrina e a jurisprudência a reconhecer os danos estéticos como uma espécie autônoma de dano extrapatrimonial (Súmula n. 387 do STJ), bem como o art. 223-B, introduzido na CLT pela Lei n. 13.467/2017, positivou os danos existenciais.

Os danos materiais, segundo o art. 950 do Código Civil, são divididos nas espécies dos danos emergentes, lucros cessantes e pensionamento, somando-se às três espécies de danos extrapatrimoniais já citadas, que são os danos morais, estéticos e os existenciais, todos os seis passíveis de serem identificados, isolada ou simultaneamente, em um acidente de trabalho.

Por fim, o último pressuposto da responsabilidade é o nexo causal, que é o mais complexo deles e objeto de muita confusão, principalmente pelo fato do seu conceito ser diverso para o direito previdenciário e a responsabilidade civil.

O nexo de causalidade é a verificação da relação de causa e efeito entre o ato ilícito praticado e o dano sofrido pela vítima. É a verificação concreta de que o ato ilícito (culposo, doloso ou resultante de uma atividade objetivamente considerada) foi o desencadeante direto do dano ou prejuízo (patrimonial ou extrapatrimonial).

Há hipóteses de responsabilidade civil sem culpa - na modalidade objetiva - assim como há possibilidade de responsabilidade mesmo sem a prática de atos ilícitos, entretanto não há dever de indenizar sem a comprovação do nexo causal, em quaisquer das modalidades de responsabilidade civil, daí porque o entendimento do referido pressuposto é indispensável.

Três foram as teorias mais difundidas para tentar explicar o requisito do nexo de causalidade, de forma que as legislações as recolheram, sendo no caso brasileiro a aceitação de uma teoria para o direito penal e previdenciário e a adoção de outra pelo direito civil.

Na síntese de Fernando Noronha, as teses explicativas da relação de causalidade procuram saber, entre todos os fatores sem os quais um determinado dano não teria ocorrido, quais devem ser selecionados como dele determinantes. ${ }^{27}$

Para a teoria da equivalência dos antecedentes, desenvolvida no Direito Penal do Século $\mathrm{XIX}$, chegou-se à conclusão de que uma conduta deve ser considerada causa sempre que se puder dizer que o dano não ocorreria se ela também não tivesse ocorrido. Há nexo causal sempre que puder ser atribuído a uma conduta um dano, ainda que remotamente e que outras condutas também tenham influído na materialização do dano. Decorre dela que o agente da conduta responde não só pelos danos diretos como pelos danos indiretos ou subsequentes.

${ }^{27}$ NORONHA, Fernando. O nexo de causalidade na responsabilidade civil. Revista dos Tribunais, São Paulo, ano 92, vol. 816, p. 733-752, outubro 2003. 
Quando mais de uma condição for identificada como geradora de um dano, todas elas são consideradas causas eficientes e equivalentes, deixando o observador de investigar qual delas foi a imediata ou a mais adequada a causar o prejuízo. Todos os antecedentes que integram a cadeia de fatos que geraram o dano são considerados causas, não importando com a ligação direta e imediata ou apenas se é remota. Para essa teoria também é irrelevante a investigação do grau de participação de cada uma das causas no evento-dano. Ao contrário, a teoria admite a conclusão abstrata de que as atuações das causas são equivalentes e, por consequência, a responsabilidade civil dos múltiplos agentes é solidária.

Nada obstante o prestígio da teoria durante algum período na Europa, a legislação civil brasileira sempre foi a ela refratária, pelo que diz Gustavo Tepedino que "a inconveniência desta teoria, logo apontada, está na desmensurada ampliação, em infinita espiral de concausas, do dever de reparar, imputado a um sem-número de agentes. Afirmou-se, com fina ironia, que a fórmula tenderia a tornar cada homem responsável por todos os males que atingem a humanidade." 28

Rejeitada pelo direito civil, a teoria da equivalência dos antecedentes foi acolhida pelo direito penal (art. 13 do Código Penal)29 e pelo direito previdenciário (Lei 8.213/1991). Na dicção legal quanto às concausas, considera a lei especial como de responsabilidade do INSS o dano, ainda que outras causas, embora mais eficientes e adequadas, tenham contribuído para o resultado. É, pois, irrelevante para a legislação previdenciária que as condições de trabalho sejam apenas uma das diversas causas - inclusive a mais leve -, bastando que tenha contribuído minimamente para o sinistro, quando o nexo causal fica estabelecido e surge a responsabilidade do órgão previdenciário pelo pagamento do benefício pelo seu valor integral.

Fica claro que a invocação do art. 21, I, da Lei n. 8.213/1991, para reconhecer a existência do nexo causal ou concausal nas ações de responsabilidade civil por acidente de trabalho, gera a inadequada importação da teoria da equivalência dos antecedentes para as relações jurídicas de natureza civil, violando a opção legislativa brasileira, bem como trazendo a drástica consequência da imputação de responsabilidade civil ao empregador, na modalidade por risco integral, em situações em que não tenha sido ele o autor da causa direta, relevante e imediata a produzir o resultado.

Fernando Noronha observa que no "âmbito da responsabilidade civil, a teoria da equivalência de condições levaria absurdamente longe demais a obrigação de indenizar."30

28 TEPEDINO, Gustavo. Notas sobre o nexo de causalidade. Revista Jurídica, ano 50, n. 296, p. 7-18, junho 2002.

29 "O nosso Código, ao resolver a questão do nexo de causalidade, adotou a teoria da conditio sine qua non ou da equivalência dos antecedentes causais. (...) Atribui relevância causal a todos os antecedentes do resultado, considerando que nenhum elemento, de que depende a sua produção, pode ser excluído da linha de desdobramento causal." (JESUS, Damásio E. de. Direito Penal. 23 ed. São Paulo: Saraiva, 1999, vol. 1, p. 249-250).

30 Op. cit., p. 736. 
Avançamos para compreender que o art. 1.060 do Código Civil brasileiro de 1916 recolheu a mesma redação dos códigos civis francês e italiano, em cujas disposições constava que somente as consequências diretas e imediatas do inadimplemento das obrigações eram alcançadas pelo dever de indenizar.

Por conseguinte, muitos autores, entre os quais Agostinho Alvim, desenvolveram a teoria da interrupção do nexo causal, para a qual

Suposto certo dano, considera-se causa dele a que lhe é próxima ou remota, mas, com relação a esta última, é mister que ela se ligue ao dano, diretamente. Assim, é indenizável todo dano que se filia a uma causa, ainda que remota, desde que ela seja causa necessária, por não existir outra que explique o mesmo dano. Quer a lei que o dano seja efeito direto e imediato da execução. ${ }^{31}$

A doutrina de Agostinho Alvim explica que a teoria da causalidade direta não afasta os danos indiretos ou remotos do dever de ressarcimento, só por essa sua natureza. Em regra, os danos indiretos ou remotos não são indenizáveis porque deixam de ser efeito necessário do ato ilícito, pelo aparecimento de concausas sucessivas, as quais rompem com o nexo causal. Mas quando se possa ligar um dano indireto ao ato ilícito remoto, sem a ocorrência de outras concausas que rompam com a cadeia causal, os danos reflexos também serão indenizáveis. ${ }^{32}$

Justamente por intervirem na cadeia causal, rompendo com o nexo em face de ato anterior que deu início aos acontecimentos, que são considerados excludentes do nexo causal o caso fortuito, a força maior, a falta exclusiva da vítima e o fato de terceiro. Em todos esses casos há ato originário praticado pelo agente ofensor, contudo, sucessivamente, interveio um ato não imputável a ele que rompeu com o nexo, daí porque os danos deixaram de ser efeitos diretos do ato ilícito originário.

A teoria da interrupção do nexo causal encontra-se em posição intermediária em relação à teoria anterior, já que enquanto para a da equivalência das condições toda e qualquer causa que tenha, direta ou indiretamente, participado do resultado é relevante juridicamente, a da interrupção do nexo causal elege como causas as que tenham contribuído necessariamente para o resultado, ainda que o dano seja uma consequência reflexa, porém importando que a causa seja a sua explicação, sem que outra posterior tenha intervido e interrompido a cadeia causal. Essa teoria admite a existência de concausas, na medida em que identificadas duas ou mais causas que tenham, necessariamente, contribuído para o resultado, sendo elas relevantes juridicamente para o estabelecimento da responsabilidade.

O exemplo doutrinário clássico para explicar essa teoria é aquele em que um agente fere outro com instrumento cortante, em razão de que a vítima é encaminhada ao hospital, contudo vem a falecer no trajeto devido ao capotamento da ambulância. Sem a ocorrência da lesão, a

${ }^{31}$ ALVIM, Agostinho. Da inexecução das obrigações e suas consequências. 4 ed. São Paulo: Saraiva, 1972, p. 356.

32 Op. cit., p. 370. 
vítima não estaria sendo conduzida na ambulância, fato que afastaria a sua morte, isso se todas as condições, remotas e próximas, fossem consideradas, como na teoria da equivalência das condições.

Entretanto, para a ideia da interrupção do nexo causal, somente as lesões corporais são os danos diretos e imediatos decorrentes do ato ilícito praticado, mas não a morte, na exata medida em que $o$ ato posterior (acidente automobilístico) interrompeu a cadeia causal, com ele não guardando nenhuma relação direta de necessariedade.

Logo, neste exemplo, poderia falar em responsabilidade civil do agente causador da lesão apenas pelos efeitos desta, mas a responsabilidade pela morte somente é atribuível ao causador da colisão automobilística.

Também há atendimento do requisito do nexo causal nas omissões em que o agente estava obrigado a agir, por imposição legal, contratual ou em razão de uma conduta anterior do próprio agente omisso. Ele não praticou o ato que deu origem ao dano, mas se omitiu na prática de outro ato que evitaria que a cadeia causal se completasse. Assim, quando não houver a imposição de um agir, não há responsabilidade civil daquele que se omitiu, ainda que tenha consciência da ocorrência premente de uma possível lesão.

Já sob os influxos da Constituição de 1988, o Supremo Tribunal Federal teve de decidir uma ação de indenização movida contra o Estado do Paraná em razão da ocorrência de assalto praticado por fugitivo de uma penitenciária estadual. A alegação da petição inicial era da responsabilidade do ente federado pela omissão na custódia do preso, ato que desencadeou o dano. A decisão foi tomada à unanimidade no sentido de que não havia responsabilidade, já que o assalto não era decorrência direta e imediata da omissão de custódia, sendo decisivas para o dano outras causas não atribuídas ao Estado do Paraná.

$\mathrm{Na}$ decisão, a teoria abonada foi a da interrupção do nexo causal. O relator Min. Moreira Alves, então Professor de Direito Civil da USP e com apoio nas lições de Agostinho Alvim, disse em seu voto que:

Em nosso sistema jurídico, como resulta do disposto no artigo 1.060 do Código Civil, a teoria adotada quanto ao nexo de causalidade é a teoria do dano direto e imediato, também denominada teoria da interrupção do nexo causal. Não obstante aquele dispositivo da codificação diga respeito à impropriamente denominada responsabilidade contratual, aplica-se ele também à responsabilidade extracontratual, inclusive a objetiva, até por ser aquela que, sem quaisquer considerações de ordem subjetiva, afasta os inconvenientes das outras duas teorias existentes: a da equivalência das condições e a da causalidade adequada. ${ }^{33}$

${ }^{33}$ STF - 1 ${ }^{\mathrm{a}}$ Turma - RE n. 130.764 - Rel. Min. Moreira Alves - DJ 07.08.1992. 
A partir da posição expressa firmada no precedente, os civilistas brasileiros, entre os quais Gustavo Tepedino, disseram que a "adoção, pelo Supremo Tribunal Federal brasileiro, da teoria do dano direto e imediato afasta a aplicação das duas outras teorias conhecidas pela dogmática do direito civil: as teorias da equivalência das condições e a da causalidade adequada." 34

Muito embora o leading case fora firmado a partir da interpretação do art. 1.060 do Código Civil de 1916, o precedente continua válido na vigência do Código Civil de 2002, eis que o atual art. 403 reproduz a literalidade do anterior, opinião que também é compartilhada pelos autores contemporâneos ${ }^{35} \mathrm{e}$ a jurisprudência dos tribunais superiores ${ }^{3637}$, com a ressalva da própria doutrina de que a jurisprudência, aqui e acolá, tem oscilado quanto à sua aplicação em casos concretos mais limítrofes, flexibilizando-a ${ }^{38}$.

Como conclusão, podemos afirmar que o sistema pátrio de responsabilidade civil, quanto ao requisito do nexo de causalidade, adotou a teoria da causalidade direta e imediata ou da interrupção do nexo causal, para a qual deve o juiz investigar no caso sobre apreciação se o dano é decorrência direta da conduta ilícita apontada como sua causadora. Apenas a resposta afirmativa instaura a relação causal imprescindível para a responsabilização civil, incluindo todos os casos de acidentes de trabalho. A segunda decorrência é o afastamento da teoria da equivalência dos antecedentes, aplicável apenas no direito penal e previdenciário.

\subsection{Excludentes do nexo de causalidade}

Na responsabilidade subjetiva, a compreensão do sistema jurídico leva à conclusão da existência de quatro excludentes da relação de causalidade, que são o caso fortuito, a força maior, o fato de terceiro e o fato da vítima, inadvertidamente chamado de "culpa exclusiva da vítima". A constatação no caso concreto de que ao menos uma das quatro excludentes estão presentes cujo ônus da prova é da defesa, já que fato extintivo do direito do autor da ação - rompe com a

\footnotetext{
${ }^{34}$ Op. cit., p. 9.

${ }^{35}$ Pablo Stolze Gagliano e Rodolfo Pamplona Filho: "Alinhamo-nos ao lado daqueles que entendem mais acertado o entendimento de que o Código Civil brasileiro adotou a teoria da causalidade direta e imediata (teoria da interrupção do nexo causal), vertente da causalidade necessária." (Novo Curso de Direito Civil. Responsabilidade civil. 3 ed. São Paulo: Saraiva, 2005, p. 104). Também defendendo a mesma posição Carlos Roberto Gonçalves: "Das várias teorias sobre o nexo causal, o nosso Código adotou, indiscutivelmente, a do dano direto e imediato, como está expresso no art. 403." (Responsabilidade Civil. 8 ed. São Paulo: Saraiva, 2003, p. 524).

36 "Sendo que o sistema civil pátrio adotou, indubitavelmente, a teoria da causalidade direta e imediata ou da interrupção do nexo causal no que se refere ao nexo de causalidade." (TST - 5 a Turma - ARR n. 00024583.2014.5.21.0010 - Rel. Min. Breno Medeiros - DEJT 03.05.2019).

37 "NECESSIDADE DE EXISTÊNCIA DE NEXO CAUSAL. ADOÇÃO DA TEORIA DA CAUSALIDADE DIRETA OU IMEDIATA, TAMBÉM CONHECIDA COMO TEORIA DA INTERRUPÇÃO DO NEXO CAUSAL. ART. 403 DO CODIGO CIVIL. APLICABILIDADE À RESPONSABILIDADE CIVIL EXTRACONTRATUAL." (STJ - 2 ${ }^{\text {a }}$ Turma - Aglnt no AREsp n. 1.518.617 - Rel. ${ }^{a}$ Min. ${ }^{a}$ Assusete Magalhães - DJe 10.03.2020).

38 MARANHÃO, Ney. Responsabilidade civil objetiva pelo risco da atividade: uma perspectiva civilconstitucional. São Paulo: Método, 2010, p. 187-195.
} 
relação jurídica de responsabilidade civil, isentando o indicado causador do dano de qualquer condenação. ${ }^{3940}$

Basta a comprovação de que não houve atuação do alegado ofensor para romper o dever de indenizar; não precisando provar qual a razão de sua isenção: se relacionada a fato humano ou a fato da natureza. Disso segue que a ausência de um ato direto seu, o que pode ser verificado nas hipóteses de caso fortuito, força maior, fato da vítima ou fato de terceiro, são suficientes para excluir os efeitos da responsabilidade civil subjetiva.

De outro lado, nos sistemas de responsabilidade civil objetiva, embora dispensados os dois requisitos gerais do ato ilícito e da culpa, remanesce a necessidade de comprovação do dano e do nexo causal, razão pela qual também são alegáveis algumas excludentes como tese de defesa, com o objetivo de romper o nexo e a obrigação de indenizar nessa modalidade mais gravosa de responsabilização.

Porém, é necessária a adaptação em relação à excludente do caso fortuito, que passa a ser subdividido em interno e externo, na linha do art. 1.147 do Código Civil francês ("cause étrangère"), que orientou a aprovação do nosso art. 393 do Código Civil de 2002, sendo que, na responsabilidade objetiva, apenas o fortuito externo, sem relação com os riscos inerentes à atividade, é que atuaria como excludente de nexo causal. ${ }^{4142}$

Agostinho Alvim esclarece os dois níveis de excludentes ao asseverar que se "a responsabilidade fundar-se na culpa, bastará o caso fortuito para exonerar o devedor", porém "se a responsabilidade de devedor fundar-se no risco, então o simples caso fortuito não o exonerará. Será mister haja força maior, ou, como dizem alguns, caso fortuito externo."

\footnotetext{
39 Por todos: "As situações reconhecidas como suficientes para romper o nexo de causalidade entre o agente sobre quem se investiga a conduta e/ou atividade e o dano sofrido pela vítima são em parte previstas originalmente na lei, e em parte decorrentes de construção doutrinária e jurisprudencial. Tradicionalmente, usa-se mencionar três situações no âmbito do direito privado como excludentes de responsabilidade civil: a) o fato exclusivo da vítima (ou simplesmente fato da vítima); b) o fato exclusivo de terceiro (ou simplesmente fato de terceiro); e c) o caso fortuito e a força maior." (MIRAGEM, Bruno. Direito Civil. Responsabilidade Civil. São Paulo: Saraiva, 2015, p. 240).

40 "(...) configurada alguma causa excludente da responsabilidade civil, notadamente o caso fortuito, a força maior ou a culpa exclusiva da vítima ou de terceiro." (STJ - $3^{\text {a }}$ Turma - REsp. n. 1.136 .885 - Rel. ${ }^{a}$ Min. ${ }^{a}$ Nancy Andrighi - DJe 07.03.2012).

${ }^{41}$ Nesse sentido a doutrina contemporânea de Ana Frazão: "Afinal, no âmbito da responsabilidade objetiva pelo risco, o juízo a ser feito é o de analisar se determinado dano encontra-se ou não na esfera do risco de determinada atividade, pois somente quando for alheio ao risco é que se poderá afastar a responsabilidade." (Risco da empresa e responsabilidade por acidentes de trabalho. Revista LTr, São Paulo, vol. 80, n. 10, p. 1179-1193, out. 2016).

42 "Por consistir em risco ligado à atividade do sujeito responsável, o fortuito interno tem sido considerado insuficiente para o afastamento da relação de causalidade entre a atividade desenvolvida e o dano, mesmo quando imprevisível e irresistível. Em outros termos: aos tradicionais requisitos da imprevisibilidade e irresistibilidade do caso fortuito, tem-se acrescentado esta terceira exigência - a externalidade ou externidade do caso fortuito, sem a qual se conserva a responsabilidade." (SCHREIBER, Anderson. Novos paradigmas da responsabilidade civil: da erosão dos filtros da reparação à diluição dos danos. 5 ed. São Paulo: Atlas, 2013, p. 68-69).
} 
E arremata com precisão: "A força maior, portanto, é o fato externo que não se liga à pessoa ou à empresa por nenhum laço de conexidade. Enquanto o caso fortuito, propriamente, traduz a hipótese em que existe aquele nexo."43

Já Fernando Noronha ensina que a responsabilidade civil objetiva é independente de culpa e ato ilícito, mas não dispensa os outros dois requisitos e, em especial, exige que haja um nexo de causalidade adequado entre a atividade do agente e o dano. Decorre daí que cessa o liame de responsabilidade civil, rompendo com o nexo causal, quando provado que o dano é devido ao fato que, em relação ao agente, seja externo, imprevisível e irresistível, isto é, quando o agente comprovar que o dano se deve a caso fortuito externo, força maior, fato de terceiro ou fato da vítima, nas hipóteses em que a responsabilidade é classificada como objetiva. ${ }^{445}$

Sublinhe-se que apenas nos casos de responsabilidade civil objetiva e agravada, em quaisquer dos microssistemas existentes ${ }^{46}$, é que o legislador optou por retirar da possibilidade da defesa uma ou algumas (jamais todas) das excludentes de nexo causal, como no acidente de transporte (art. 734 do Código Civil), em que o legislador disse não socorrer ao transportador a alegação de fato de terceiro (art. 735 do CC), inserindo-se esses riscos especiais em sua responsabilidade agravada (fortuito interno), mas os fatos da própria vítima ou os casos de força maior, romperiam a sua obrigação de indenizar, mesmo na atividade de agravado risco, como no caso de um deslizamento involuntário de terras, que viesse a atingir o veículo do empregador $e$ soterrar os trabalhadores transportados, p. ex.

É decisivo anotar que não se deve confundir a responsabilidade objetiva pelo risco da atividade com aquela extrema por risco integral (presente apenas na responsabilidade do INSS com o segurado e no seguro DPVAT), isso porque, a despeito de a atividade desenvolvida pelo empregador ser de risco em várias hipóteses e, por isso, a responsabilidade ser objetiva, sempre há a possibilidade da isenção da obrigação de indenizar quando comprovar a ocorrência de uma das hipóteses excludentes de nexo causal.

Para tanto, basta imaginar a situação singela da atividade de motoboy, que exerce atividade de risco e a responsabilidade é objetiva, mas ele próprio, em alta velocidade, avança o semáforo fechado e vem a sofrer danos em consequência de uma colisão, hipótese em que há rompimento do nexo causal a partir do fato da própria vítima, muito embora o mesmo evento seja considerado acidente de trabalho para fins previdenciários (risco integral).

43 Op. cit., p. 315-316.

${ }^{44}$ NORONHA, Fernando. Responsabilidade civil: uma tentativa de ressistematização. Revista de Direito Civil, São Paulo, ano 17, n. 64, p. 12-47, abr.-jun. 1993.

${ }^{45} \mathrm{~A}$ lição foi acolhida e consagrada na jurisprudência do Superior Tribunal de Justiça. Por todos: "A força maior deve ser entendida, atualmente, como espécie do gênero fortuito externo, do qual faz parte também a culpa exclusiva de terceiros, os quais se contrapõem ao chamado fortuito interno. $O$ roubo, mediante uso de arma de fogo, em regra é fato de terceiro equiparável a força maior, que deve excluir o dever de indenizar, mesmo no sistema de responsabilidade civil objetiva." (STJ - 4a Turma - REsp. n. 976.564 - Rel. Min. Luis Felipe Salomão - DJe 23.10.2012).

${ }^{46}$ Consultar: MOLINA, André Araújo. Sistemas de responsabilidade civil objetiva e os acidentes de trabalho. Revista do TST, São Paulo, vol. 79, n. 2, p. 70/117, abr./jun. 2013. 
Erick Frederico Gramstrup observou que há uma forte tendência em se confundir responsabilidade civil objetiva com a responsabilidade por risco integral, que são diferentes. Afirma ele que não se pode extrair da desnecessidade de provar a culpa que não haja outros requisitos, notadamente as excludentes de responsabilidade, no que chamou de "salto heroico" o que é praticado por grande parte dos autores ao derivar da objetivação da responsabilidade a integralidade do risco e a certeza da condenação. ${ }^{47}$

O "salto heroico" também é observado, com muita frequência, na jurisprudência ${ }^{4849} \mathrm{e}$ doutrina ${ }^{50}$ trabalhistas, quando reconhecem que a atividade desenvolvida pelo trabalhador é de risco e a responsabilidade civil do empregador é objetiva, já avançando para a condenação automática pelos danos sofridos pelos empregados no exercício da atividade, sem investigar o requisito do nexo de causalidade (ou quais das excludentes estariam presentes naquele caso).

Também é comum alguns julgados especializados não admitirem o fato de terceiro como excludente de nexo causal, justamente por confundirem a responsabilidade civil objetiva com a responsabilidade civil por risco integral, o que é potencializado quando é invocada a Lei $\mathrm{n}$. 8.213/1991 como fundamento para o julgamento dos pedidos de responsabilidade civil.

Mas em todos os casos em que o empregador, seja na modalidade subjetiva ou na objetiva, pela atividade de risco, for isento da condenação nas ações de responsabilidade civil ajuizadas na Justiça do Trabalho, porque comprovada alguma das excludentes, o trabalhador acidentado e seus familiares não ficarão desassistidos, eis que o evento caracterizar-se-á como um acidente de trabalho previdenciário (Lei n. 8.213/1991), atraindo a proteção da Previdência Social, bem como os reflexos indiretos no contrato de trabalho, como são o recolhimento do FGTS do período da licença e o retorno com garantia provisória de emprego, sem contar uma eventual indenização amparada em seguro privado atrelado ao contrato de trabalho.

47 GRAMSTRUP, Erick Frederico. Responsabilidade objetiva na cláusula geral codificada e nos microsistemas. In: DELGADO, Mário Luiz; ALVES, Jônes Figueiredo (coord.). Novo Código Civil. Questões Controvertidas. Responsabilidade Civil. São Paulo: Método, 2006, p. 139.

48 "Partindo dessa linha de visada, concluo que estamos diante de um caso de típica responsabilização civil objetiva, sem excludentes, onde não cabe perquirir a culpa ou dolo do empregador, devendo este simplesmente arcar com o ônus do seu empreendimento, que, no caso, redundou na exposição diária de seu empregado a risco acentuado, provado em razão do acidente que vitimou o autor, em razão do risco acentuado de sua atividade." (TRT 23a Região - 1ª Turma - RO n. 0000194-41.2013.5.23.0046 - Red. Desig. Des. Osmair Couto - DEJT 07.10.2013).

49 "ACIDENTE DE TRABALHO - DANOS MORAL, ESTÉTICO E MATERIAL - Não cabe, na hipótese, discutir se a culpa é do empregador, se fato de terceiro, caso fortuito ou força maior, já que a responsabilidade no caso é objetiva, pautada na teoria do risco integral." (TRT $1^{\text {a }}$ Região $-2^{\mathrm{a}}$ Turma - RO n. 024960091.2006.5.01.0341 - Rel. Des. Valmir de Araújo Carvalho - DOERJ 19.11.2014).

50 "A culpa pelo acidente de trabalho se presume diante do risco da atividade desenvolvida pelo empregador, de modo que não há excludente da responsabilidade do empregador no assalto a ônibus, em relação ao dano moral e material causados aos seus empregados." (VEIGA, Aloysio Corrêa da. Responsabilidade civil no transporte de passageiros: "assalto a ônibus e excludentes". Revista do TST, Brasília, vol. 79, n. 2, p. 42-52, abr./jun. 2013). 


\section{AGRESSÃO POR TERCEIROS ESTRANHOS À RELAÇÃO CONTRATUAL}

Aplicando a ideia do nexo de causalidade, conforme a teoria dos danos diretos e imediatos ou da interrupção do nexo causal, acolhida pelo Código Civil de 2002, pela doutrina e pela jurisprudência clássica do Supremo Tribunal Federal e dos tribunais superiores, tanto na responsabilidade subjetiva, quanto na objetiva pelo risco da atividade, a agressão sofrida pelo trabalhador por ato de terceiros que são estranhos à relação contratual, geralmente, estará fora da esfera de responsabilidade civil do empregador, justamente porque a ofensa será tida como uma excludente de fato de terceiro, equiparada ao caso fortuito externo.

Nas atividades ordinárias, sem risco acentuado e sem a inserção em nenhum dos microssistemas de responsabilidade civil objetiva, a eventual e abrupta agressão praticada por terceiros contra o trabalhador está fora do âmbito de proteção da responsabilidade da empresa, eis que verificado no caso um fato de terceiro, como na hipótese do atendente que é agredido pelo cliente do empregador, que ficou insatisfeito com o produto vendido ou o passageiro que deu socos na comissária de bordo quando ela pediu para ele usar a máscara de proteção facial. ${ }^{51}$

llustrativo acórdão do TRT da $15^{\mathrm{a}}$ Região ${ }^{52}$ enfrentou a situação de fato em que o motorista e a monitora de um ônibus de transporte escolar foram surpreendidos por um terceiro, ex-companheiro da monitora, que pretendendo atacá-la por motivos passionais, entrou em luta corporal com o motorista, que sofreu diversos e graves ferimentos por instrumento cortante.

A decisão compreendeu muito bem a questão, divisando o conceito previdenciário de acidente dos requisitos da responsabilidade civil, tendo fundamentado que, apesar dos riscos inerentes ao labor como motorista de transporte escolar, o acidente relatado nos autos não teria decorrido dos fatores inerentes aos riscos próprios da profissão, mas de evento sem relação com a atividade, embora em local e horário de trabalho, caracterizando-se como um fato de terceiro, equiparado ao fortuito externo, de modo que a decisão rejeitou os pedidos de danos morais, materiais e estéticos.

Uma situação diversa, em que haverá a responsabilidade do empregador, ocorre no caso da agressão ter sido objeto de ameaça anterior, tendo a vítima avisado os seus superiores ou o empregador dos riscos criados na hipótese, quando a omissão patronal no dever de zelar pelo meio ambiente de trabalho (precaução), naquelas especiais circunstâncias, converteria a modalidade em objetiva pelo risco da atividade (art. 927, parágrafo único, do Código Civil) e a agressão anunciada passaria a ser equiparada ao fortuito interno - previsível e evitável - que não romperia o nexo de causalidade na responsabilidade objetiva, enlaçando o empregador no dever de indenizar a vítima, remanescendo, apenas, a ação de regresso em face do ofensor.

51 <https://g1.globo.com/mundo/noticia/2021/10/28/passageiro-soca-rosto-de-comissaria-apos-ela-pedirpara-ele-colocar-mascara-em-voo-nos-eua.ghtml>

52 TRT da $15^{\mathrm{a}}$ Região - 2 ${ }^{\mathrm{a}}$ Câmara - RO n. 0010224-49.2019.5.15.0111 - Rel. ${ }^{a}$ Juíza Conv. Patrícia Penna Martins - DEJT 13.05.2021. 
Por fim, há algumas atividades ou profissões especiais em que as agressões físicas são previsíveis, prováveis, controláveis e, por isso, gerenciáveis pelos empregadores, cujos atos inserem-se nos riscos inerentes à atividade, convertendo a responsabilidade em objetiva e as agressões em meros fortuitos internos, que não rompem com o dever de indenizar, a exemplo da atividade de segurança privada em eventos, vigilância patrimonial etc.

O critério da probabilidade estatística (frequência) é decisivo para resolver os casos em que as agressões físicas de terceiros atingiram os trabalhadores de determinadas atividades, sendo adequado imaginar que, de acordo com as circunstâncias concretas especiais de algumas regiões, a mesma atividade possa ser de risco em um contexto social e não em outro, na última hipótese, p. ex., quando realizada em uma localidade mais pacata, em que, estatisticamente, não há registros de agressões físicas no exercício daquela mesma atividade profissional.

Anderson Schreiber acrescenta que: "Maior peso deve adquirir a análise dos dados estatísticos relativos a acidentes provocados, na realidade brasileira, pela atividade que se examina, adquirindo importância não apenas a quantidade de danos gerados, mas também a sua gravidade, muitas vezes já apreendidas em outras manifestações (...)." O autor avança para defender que, com acesso mais específicos aos dados, é possível "alcançar o grau de risco da própria empresa e não apenas da atividade em geral." ${ }^{53}$

Dentro desse mesmo raciocínio insere-se o tema candente da responsabilidade civil do empregador nos casos de assalto. Partimos do pressuposto que a solução generalizante de que os assaltos são um problema da segurança pública e que não são controláveis ou evitáveis pelos empregadores, isentando-os, sempre, do dever de indenizar ${ }^{54}$, não atende a complexidade das infinitas atividades e dos variados riscos assumidos pelos empregadores em cada ocasião.

Não temos dúvida alguma, p. ex., que nas atividades de transporte de valores em carroforte, atendimento bancário (incluindo-se aqui o chamado "banco-postal" e as lotéricas), transporte de mercadorias valiosas em regiões de grande índice de criminalidade, que em todos esses casos o risco de assalto e das respectivas agressões físicas são inerentes aos riscos comuns da atividade, na medida em que previsíveis, prováveis, controláveis e gerenciáveis, razões pelas quais a responsabilidade é objetiva e o assalto é mero fortuito interno, sem romper com o nexo causal e o dever de indenizar por parte dos empregadores.

Em uma audiência trabalhista, bastariam poucas perguntas ao preposto da empresa ou às testemunhas para constatar que o risco de sofrer assalto é inerente aos riscos da atividade, como a contratação de seguro privado para o evento específico, a utilização de carro blindado ou

53 Op. cit., p. 26-27.

54 "Assim, especificamente em casos como o ora em análise, a Segunda Seção desta Corte Superior firmou, há tempos, entendimento no sentido de que, não obstante a habitualidade da ocorrência de assaltos em determinadas linhas, é de ser afastada a responsabilidade da empresa transportadora por tratar-se de fato inteiramente estranho à atividade de transporte (fortuito externo), acobertado pelo caráter da inevitabilidade." (STJ - 2a Seção - Recl. n. 4.518 - Rel. Min. Ricardo Villas Bôas Cueva - DJe 07.03.2012). 
colete à prova de balas, a instalação de mecanismos de segurança e proteção rigorosos no ambiente, a ocorrência de eventos idênticos com colegas de trabalho anteriormente etc.

Esses dados fáticos são indispensáveis para decidir, v. g., se há responsabilidade civil do empregador no caso do frentista de posto de combustíveis que fora assaltado e agredido em seu local de trabalho, fazendo total diferença o contexto do ambiente de trabalho: posto em uma cidade grande, com alto índice de criminalidade na região, com o atendimento noturno e recebimento ordinário de dinheiro, cujo estabelecimento já fora assaltado tantas outras vezes, sendo diferente do posto da pequena e pacata cidade do interior, localizado em local de grande movimento e que somente atende durante o dia, cujo primeiro assalto, depois de muitos anos do empreendimento, ocorreu de modo completamente improvável e imprevisível.

As respostas tendentes à generalização, do Superior Tribunal de Justiça no sentido de que os assaltos seriam sempre tidos como um problema de segurança pública, rompendo com a obrigação de indenizar, ou do Tribunal Superior do Trabalho ao imputar, quase sempre, ao empregador a responsabilidade civil, sem avançar sobre os dados fáticos e estatísticos da situação concreta dos assaltos naquelas atividades e circunstâncias, não são soluções seguras e cientificamente adequadas.

Por isso que compreendemos, como anotado alhures, que nas demais atividades em que o risco de assalto não é previsível e nem, estatisticamente, provável, a episódica ocorrência leva ao rompimento do nexo causal, enquanto um fato de terceiro equiparado ao caso fortuito externo, sendo a vítima amparada apenas pelo INSS, na medida em que o evento fatídico não deixa de ser um acidente de trabalho para fins previdenciários, além de ser incidentes os reflexos indiretos no contrato, como a garantia provisória de emprego após a alta previdenciária.

Agora, nas situações em que a probabilidade alta de assalto está inserida nos riscos das atividades, concretamente analisadas, a responsabilidade civil do empregador passa a ser objetiva e a confirmação do evento desperta a sua responsabilização, já que fortuito interno.

\section{AGRESSÃO POR COLEGA DE TRABALHO}

Nas situações em que o trabalhador é agredido por um colega de trabalho, a resposta do ordenamento jurídico é diferente das situações de agressão por terceiros. Nessa hipótese, a regra geral é a de que o empregador responde objetivamente pelos atos dos seus empregados ou prepostos, cometidos no exercício do trabalho que lhes competir, ou em razão dele, na clara dicção do art. 932, III, do Código Civil.

Ainda no sistema do Código de 1916, o art. 1.523 somente admitia que o patrão fosse responsável por atos de outrem, quando a vítima provasse a negligência do empregador na situação, cuja prova era muito difícil de ser produzida, razão pela qual a jurisprudência do Supremo Tribunal Federal, representada pela Súmula n. 341, avançou para considerar como presumida a 
culpa do patrão pelo ato culposo cometido por seu empregado ou preposto, dando ensejo à inversão do ônus probatório, para que o empregador comprovasse a sua diligência.

O segundo avanço veio com a vigência do Código de 2002, no já citado art. 932, III, que objetivou a responsabilidade do empregador pelos atos cometidos por seus empregados ou prepostos que causem prejuízo a outrem, independentemente da demonstração ou presunção de culpa do empregador. Contudo, mesmo atualmente, continua sendo necessário que a vítima comprove a culpa do empregado ou preposto que cometeu o ato lesivo, para assim despertar a responsabilidade objetiva do empregador, pessoa natural ou jurídica, pela reparação do dano.

A norma exige que a conduta do empregado ou preposto ${ }^{55}$, apta a responsabilizar objetivamente o empregador, é aquela praticada no exercício do trabalho que lhe competia ou em razão dele ${ }^{56}$, mesmo que em abuso da função ${ }^{57}$, colocando uma linha divisória no sentido de que não haverá responsabilidade civil do empregador, apenas do causador direto, quando o ato lesivo praticado pelo preposto não guardar relação com o trabalho, ainda que seja praticado, em situações limites, dentro do local e no horário de trabalho.

Bruno Miragem observa que:

A responsabilidade do empregador decorre da circunstância de o dano ter sido realizado em razão do trabalho desenvolvido. Ou seja, deve haver vínculo lógico entre o exercício da atividade laboral pelo empregado e o dano causado, de modo a caracterizar o risco que lhe é inerente. Ou seja, deveria e deve haver conexão entre a conduta do empregado que dá causa ao dano e sua relação com o empregador. (...) Basta para caracterizar o responsabilidade do empregador que o dano praticado pelo empregado se dê a partir de ato caracterizado no âmbito do exercício normal de suas atribuições. ${ }^{58}$

\footnotetext{
55 Não se deve confundir o conceito de preposto trabalhista (art. $843, \S 1^{\circ}$, da CLT) com o conceito civilista, na medida em que - para fins de responsabilidade civil - funciona como preposto qualquer pessoa, natural ou jurídica, que faça as vezes do empregador, que pratica atos em seu nome, motivo pelo qual é irrelevante para a responsabilização se o causador do dano era um empregado, autônomo, prestador de serviço ou mero colaborador eventual, inclusive atraindo a responsabilidade do empregador nos casos de atos praticados pelos terceirizados, em nome do empregador e no exercício da atividade, como no caso de um agente de portaria terceirizado que agride fisicamente algum cliente ou mesmo os seus colegas de trabalho, empregados diretos ou também terceirizados, sem prejuízo de eventual ação de regresso em face do próprio causador do dano ou do empregador direto dele (fornecedora de mão-de-obra), conforme cláusulas da contratação comercial entre eles (Neste sentido: STJ - 4ª Turma - Aglnt no AREsp n. 1.347.178 - Rel. Min. Raul Araújo - DJe 24.04.2019).

${ }^{56}$ Carlos Roberto Gonçalves leciona que: "Para que haja responsabilidade do patrão por ato do preposto, é necessário que concorram três requisitos, cuja prova incumbe ao lesado: $1^{\circ}$ ) qualidade de empregado, serviçal ou preposto, do causador do dano (prova de que o dano foi causado por preposto); $2^{\circ}$ ) conduta culposa (dolo ou culpa stricto sensu) do preposto; $3^{\circ}$ ) que o ato lesivo tenha sido praticado no exercício da função que lhe competia, ou por ocasião dela." (Responsabilidade Civil. 8 ed. São Paulo: Saraiva, 2003, p. 123).

57 "Nenhuma importância tem a circunstância de o dano resultar de ato praticado contra as ordens do empregador. Se o empregado, com o carro da empresa, desviou-se da rota ordenada, ou dirigiu de forma abusiva, contra as instruções do seu chefe, tais circunstâncias em nada alteram a responsabilidade solidária do empregador." (FARIAS, Cristiano Chaves de; ROSENVALD, Nelson; BRAGA NETTO, Felipe Peixoto. Curso de Direito Civil. Responsabilidade Civil. 4 ed. Salvador: Juspodivm, 2017, vol. 3, p. 571). No mesmo sentido: STJ - 4 ${ }^{a}$ Turma - REsp n. 1.365.339 - Rel. ${ }^{a}$ Min. ${ }^{a}$ Isabel Gallotti - DJ 16.04.2013.

58 Op. cit., p. 317.
} 
Sílvio de Salvo Venosa, dentro da mesma compreensão, acrescenta que, inobstante seja objetiva a responsabilidade do empregador pelos atos praticados pelos seus prepostos, a ele restará provar "que o dano não foi causado no exercício do trabalho ou em razão dele."59

Deveras, é muito singelo compreender que nem todos os atos praticados por um cidadão, circunstancialmente sócio de uma pessoa jurídica LTDA, obrigará, civilmente, esta, mas apenas os atos que forem praticados no exercício do poder de administração da entidade, da mesma forma que os atos praticados por outro cidadão, circunstancialmente empregado ou vestido com o seu uniforme de trabalho, vai atrair a responsabilidade do seu empregador, mas apenas os atos lesivos que forem praticados no exercício do trabalho que the competia ou em razão dele, ainda que em abuso da função e das tarefas que lhes foram delegadas.

Por essas razões, discordamos, no ponto, de renomados autores trabalhistas, como Raimundo Simão de Melo ${ }^{60}$ e Cláudio Brandão ${ }^{61}$, que sem fazer a distinção entre as esferas previdenciária e de responsabilidade civil, conjugam os requisitos da Lei n. 8.213/1991 com o art. $2^{\circ}$ da CLT e a leitura alargada do art. 932, III, do Código Civil, para concluir que, durante a prestação de serviços, o empregado está sob os cuidados e a responsabilidade do empregador, de modo que qualquer dano causado ao colega de trabalho amoldar-se-á ao conceito de acidente previdenciário, atraindo a responsabilidade civil pelas consequências decorrentes.

O ponto destacado é de suma importância ser compreendido, na medida em que, havendo ou não relação da ofensa com o exercício do trabalho que competia ao agressor, certo é que o evento será tido como um acidente de trabalho previdenciário, com objetivos sociais e protetivos amplos - até quando a ofensa ocorreu no intervalo, em disputas desportivas ou em viagem para estudos, conforme art. 21 , II e $\S 1^{\circ}$, da Lei n. 8.213/1991 -, porém somente quando o ato lesivo guardar relação com o exercício do trabalho ou tiver sido cometido em razão da atividade é que haverá, também, a responsabilidade civil do empregador.

Concluímos que a regra geral é a de que o empregador responderá de forma objetiva pelas agressões que os empregados ou prepostos cometerem em face dos colegas de trabalho, afastando-se a responsabilidade somente nos casos-limite em que a defesa comprovar que o ato abrupto não guarda nenhuma relação com o trabalho, p. ex., uma agressão física cometida no refeitório da empresa, por motivo estritamente pessoal, sobre o qual o empregador não tinha ciência e, por isso, não havia como prever, controlar e gerenciar, assimilando-se ao caso fortuito externo, completamente alheio aos riscos empresariais, mesmo na responsabilidade objetiva.

${ }^{59}$ VENOSA, Sílvio de Salvo. Direito Civil. Responsabilidade Civil. 3 ed. São Paulo: Atlas, 2003, vol. 4, p. 68. 60 MELO, Raimundo Simão de. Ações acidentárias na Justiça do Trabalho. São Paulo: LTr, 2011, p. 103-104.

${ }^{61}$ BRANDÃO, Cláudio. Acidente do trabalho e responsabilidade civil do empregador. São Paulo: LTr, 2006, p. 208-209. 


\title{
6. REVISÃO DA JURISPRUDÊNCIA DO TRIBUNAL SUPERIOR DO TRABALHO
}

A $6^{\text {a }}$ Turma do TST62, em decisão recente e muitíssimo elogiável, debruçou-se sobre a hipótese fática em que uma trabalhadora foi vítima de tentativa de feminicídio, no horário e local de trabalho, por disparos de arma de fogo efetuados pelo ex-companheiro, que resultaram em lesões físicas que culminaram no seu afastamento do labor por um longo período.

O acórdão, primeiro, divisou o enquadramento previdenciário da responsabilidade civil, dizendo que a agressão sofrida, na forma do art. 21, II, "a", da Lei n. 8.213/1991, se equipara a acidente de trabalho, havendo responsabilidade objetiva do INSS pela concessão de benefício previdenciário, mas que as pretensões de responsabilidade civil, objeto do recurso, deveriam ser apreciadas à luz dos pressupostos próprios. Destaque-se da fundamentação:

\begin{abstract}
Porém, a responsabilidade objetiva do INSS no campo previdenciário não se confunde com a responsabilidade da empregadora na esfera cível. O fato de o infortúnio se enquadrar como acidente de trabalho não implica necessariamente a responsabilidade civil da empresa, fazendo-se necessário, nesse particular, o exame dos requisitos previstos nos arts. 186 e 927 do Código Civil.
\end{abstract}

Avançou para dizer que, em que pese o ato de violência ocorrido na sede da empresa ter causado danos imensuráveis à trabalhadora, juridicamente, é fato imprevisível e inevitável, alheio às atividades da empresa e da empregada, inclusive porque não havia no acórdão regional nenhuma notícia de que a vítima já tivesse alertado a empregadora de que era beneficiária de medida protetiva, razões pelas quais a Corte concluiu que o episódio se amolda à situação de caso fortuito externo, gerando a rejeição dos pedidos de danos morais, materiais e estéticos.

Nesta mesma linha de entendimento, em outro julgado recente ${ }^{63}$, o Tribunal, a partir da premissa da distinção das esferas previdenciária e de responsabilidade civil, avançou para divisar, novamente, que o último sistema, seja na responsabilidade subjetiva, seja na objetiva, pressupõe, necessariamente, a comprovação do nexo causal, não se devendo confundir o risco integral com a teoria do risco da atividade (responsabilidade objetiva).

Logo, no caso concreto, era "inviável, pois, condenar o empregador ao pagamento de indenização por dano moral sem comprovação detida do nexo causal.", mesmo que a atividade fosse de risco.

Uma terceira decisão, de outra turma de julgamento, captou o exato sentido de não se pode misturar os sistemas protetivos previdenciário e de responsabilidade civil, previstos no art. $7^{\circ}, \mathrm{XXVIII}$, da Constituição, que têm fundamentos, objetivos e requisitos diferentes:

62 TST $-6^{a}$ Turma - ARR n. 001688-63.2014.5.05.0641 - Rel. $^{a}{ }^{\text {Min. }}{ }^{a}$ Kátia Magalhães Arruda - DEJT
14.02.2020.
63 TST $-6^{\text {a }}$ Turma - ARR n. 000331-57.2014.5.11.0002 - Rel. ${ }^{a}$ Min. $^{a}$ Kátia Magalhães Arruda - DEJT
28.06. 28.06.2019. 
Nesse sentido, a principiologia da seguridade social, mais elástica, protetiva, assistencialista e socializante do dano, orientada para uma responsabilidade de viés de risco integral, e dirigida ao Estado e à sociedade, de uma forma geral, nos termos do art. 194 da CF, não pode ser aplicada da mesma forma ao direito comum, bem assim ao direito do trabalho, que encontra, na lei, limites à responsabilização do empregador, tendo por fiel da balança a caracterização do nexo causal. ${ }^{64}$

Muito embora a retidão das decisões inventariadas, fato é que ainda há algum vacilo em torno do tema da separação das esferas previdenciária e a responsabilidade civil no Tribunal Superior do Trabalho, podendo-se dizer que a maioria dos acórdãos ainda buscam fundamento na Lei n. 8.213/1991 quando estão a julgar as pretensões de responsabilidade civil, como na situação em que a empregada faleceu durante a realização de uma cirurgia (tromboembolismo pulmonar), que foi a causa única e imediata para a morte.

Neste caso, o acordão do TST ${ }^{65}$, a partir da ideia previdenciária de concausa e do alargado conceito de nexo causal (teoria da equivalência dos antecedentes), considerou que o empregador seria o responsável pelas indenizações por danos moral e material, na medida em que se não fosse o acidente de trabalho (fratura do pé direito ao pisar em falso em um pallet de madeira), a vítima não teria necessidade de submeter-se à cirurgia ortopédica, cujo ato médico acabou, pelo tromboembolismo pulmonar, gerando o falecimento.

Neste caso concreto, caso os fatos tivessem sido abordados adequadamente, a partir dos requisitos do Código Civil e, por corolário, da teoria da interrupção do nexo causal, a morte da trabalhadora não seria atribuída diretamente à empregadora, apenas, se o caso, ao médico responsável pela cirurgia e ao hospital. Porém, o empregador seria responsável apenas pelos danos diretos e imediatos causados pelo acidente de trabalho, qual seja: a fratura do pé direito, apurando-se, a partir desta premissa, se havia perda da capacidade laborativa, quais as despesas médicas, danos estéticos, danos morais, todos proporcionais à gravidade da lesão gerada pelo empregador e não pela morte que ocorreu depois, de forma indireta e independente.

Já em relação ao polêmico caso dos assaltos sofridos pelos empregados, o Tribunal Superior do Trabalho tem a tendência de imputar, sempre, a responsabilidade ao empregador, sem investigar os dados fáticos dos casos concretos, fixados nos acórdãos recorridos, flertando com a responsabilidade civil por risco integral, inaplicável na espécie, como visto acima.

Ilustrativa é a decisão da SDI-166 que fixou a premissa generalizante de que é fato notório o perigo que ronda as vias públicas do Brasil, bem por isso "o empregador que permite a ativação do empregado nas aludidas vias cria, conscientemente, risco à vida e à integridade física do

64 TST - 4a Turma - RR n. 000120-43.2017.5.08.0117 - Rel. Min. Ives Gandra Martins Filho - DEJT 28.06.2019

65 TST - 4 ${ }^{\mathrm{a}}$ Turma - AIRR n. 001085-08.2013.5.03.0050 - Rel. Des. Conv. José Ribamar Oliveira Lima Júnior - DEJT 21.11.2014.

66 TST - SDI-1 - E-RR n. 028900-66.2006.5.17.0007 - Rel. Min. Vieira de Mello Filho - DEJT 07.10.2011. 
obreiro. Tal criação, entretanto, não o isenta de responder pelas lesões daí oriundas, por força de norma geral de responsabilidade civil prevista nos arts. 186 e 927 do Código Civil."

A limitação da atuação da Corte para o reexame de fatos e provas (Súmula n. 126 do TST), não pode ser justificativa para a formação de uma jurisprudência generalizante na linha de que, independentemente das circunstâncias concretas, os assaltos aos trabalhadores são eventos que imputam, sempre, a responsabilidade civil aos empregadores, automaticamente.

Tais decisões, além do efeito de neutralizar as circunstâncias dos casos concretos decisivas para a definição se a violência dos assaltos são riscos inerentes ou externos àquela atividade específica e naquelas condições -, também estimulam a sua replicação automática, abstrata e generalizante, pelas instâncias ordinárias ${ }^{67}$, sem que estas - a quem incumbe o exame detido dos fatos e provas - façam a correta investigação casuística da ocorrência de um fortuito interno ou de um fato de terceiro sem relação de conexidade com os riscos inerentes à atividade, convertendo uma responsabilidade civil por risco criado em por risco integral, sem excludentes, como amiúde ainda tem ocorrido nos tribunais.

Fora do âmbito da nossa crítica acadêmica está a elogiável decisão da $7^{\text {a }}$ Turma do $\mathrm{TST}^{68}$ que, ao analisar o caso de um eletricista que foi assaltado enquanto estava a serviço da empresa, concluiu que o evento se tratou de um típico fato de terceiro, sem relação com os riscos inerentes da atividade, sendo um ato imprevisível, inevitável e externo ao empregador, rompendo com o nexo causal. O acórdão foi muito preciso ao anotar que "não se pode exigir que a reclamada adotasse conduta supostamente capaz de evitar ou minorar o dano suportado pelo autor, quando não tinha tal dever. Ressalte-se que não se tem notícia nos autos de que o reclamante tenha sido colocado em situação de risco por determinação da reclamada."

Um outro acórdão recente ${ }^{69}$ enfrentou o caso em que um motorista de aplicativo foi morto em uma briga de trânsito, por um motociclista que efetuou disparos de arma de fogo, após desentendimento verbal entre eles. Consta do acórdão que a vítima estava conectada na plataforma, para o atendimento de uma corrida, quando ocorreu a desavença que culminou com os vários disparos que ceifaram a vida do motorista, de modo que a ação ajuizada pela cônjuge do falecido buscava a condenação da UBER nas indenizações por danos moral e material.

O acórdão do TST, partindo da premissa da competência da Justiça do Trabalho, na medida em que a relação jurídica entre a plataforma e o motorista era, no mínimo, uma relação de trabalho autônomo, inserida no art. 114, I, da Constituição, avançou ao mérito do recurso para fixar a primeira premissa de que a atividade da plataforma é de transporte, atraindo a sua

${ }^{67}$ Consultar: MOLINA, André Araújo. Compreensão e aplicação dos precedentes na Justiça do Trabalho. Revista LTr, São Paulo, ano 84, n. 2, p. 165-180, fev. 2020.

68 TST - 7 $7^{\text {a }}$ Turma - RR n. 063300-32.2008.5.05.0311 - Rel. Min. Vieira de Mello Filho - DEJT 30.10.2013.

69 TST - 3 $3^{\text {a }}$ Turma - RR-Ag n. 000849-82.2019.5.07.0002 - Rel. Min. Alexandre Agra Belmonte - DEJT 17.12.2021. 
responsabilidade objetiva, tanto pelo disposto nos arts. 734 a 742 , quanto do art. 927, parágrafo único, todos do Código Civil.

Apoiando-se no art. 735 do Código Civil, a decisão afirmou que a responsabilidade objetiva do transportador não é ilidida por culpa de terceiro, contra quem teria ação regressiva. Porém, se o ato de terceiro for inevitável, imprevisível e não guardar relação de conexão com os riscos inerentes ao transporte, equipara-se ao caso fortuito externo, quando a obrigação de indenizar estaria rompida.

No caso concreto, o TST considerou que a briga no trânsito - que resultou na morte do motorista -, não pode ser equiparada ao caso fortuito externo, imprevisível, porque guardaria relação direta com a atividade perigosa e estressante de transporte em grandes cidades marcadas pela violência e, portanto, não se traduz em fato de terceiro equiparado à imprevisibilidade do fortuito apto a excluir a responsabilidade do transportador.

Acrescentou que, assim como os choques com outros veículos, estouros de pneus, malestar do motorista, perda da direção por fechada de terceiro e demais falhas mecânicas, os desentendimentos no trânsito são esperados e estão contidos nos riscos da atividade ${ }^{70}$, sendo hipótese diferente dos eventos extraordinários e imprevisíveis, como raios, enchentes, balas perdidas e apedrejamentos, quando estaria afastada a responsabilidade do transportador.

Em conclusão, o julgado do TST deu provimento ao recurso da viúva da vítima, para determinar o retorno dos autos às instâncias ordinárias, para que prossiga no julgamento dos pedidos indenizatórios decorrentes da reconhecida responsabilidade civil da plataforma.

A parte a polêmica quanto ao aspecto processual da competência material da Justiça do Trabalho, em relação ao mérito do acórdão, estamos de acordo com a sua premissa abstrata de que o cerne do julgamento estava na apuração do evento enquanto caso fortuito interno ou externo aos riscos da atividade. Porém, discordamos frontalmente do resultado que foi dado ao caso concreto.

Isso porque, além de compreendermos que os desentendimentos no trânsito que descambem para um homicídio não se inserem nos riscos inerentes à atividade, já que não há previsibilidade, controlabilidade e oportunidade de gerenciamento pela plataforma, amoldando-se ao típico fato de terceiro externo aos riscos da atividade, também vislumbramos a excludente do

\footnotetext{
70 "De fato, nas grandes cidades onde a violência é frequente, o evento ocorrido não é imprevisível em relação à atividade. $\mathrm{O}$ risco, em se tratando de transporte de passageiros por táxis e veículos de aplicativos, diz respeito não apenas à condução em relação aos passageiros, como também abrange a sujeição do motorista a acidentes por furos de pneus, mal súbito, sequestros e agressões, risco esse criado por essa atividade típica de transporte, o que o caracteriza como fortuito interno. Fortuito externo seria a bala perdida, como já antes mencionada, a árvore que cai em virtude de uma ventania, a ponte que desaba em razão de um raio no momento de atravessá-la. Além disso, o risco de se levar um tiro, tal como ocorreu na presente situação, ou de ser agredido fisicamente ou com bastão de beisebol em uma discussão está contido no estresse do trânsito e também decorre da própria violência das grandes cidades, deixando, portanto, de serem fatos estranhos a quem atua diuturnamente na atividade de transporte, assim não exonerando a responsabilidade objetiva do transportador tanto pelas pessoas por ele transportadas, como pelo profissional que por ele, como empregado ou como preposto, atua fisicamente no transporte."
} 
fato da vítima, eis que o motorista foi partícipe da discussão e não vítima unilateral - como se fosse um assalto -, além de que o motorista era agente de transporte e não, conceitualmente, um transportado, afastando a incidência do art. 735 do Código Civil, que foi aplicado no caso. ${ }^{71}$

A qualidade de segurado obrigatório do motorista no INSS, independentemente da discussão sobre o vínculo de emprego ou o trabalho autônomo, proporcionará a incidência do conceito de acidente de trabalho previdenciário na hipótese, para fins de amparar a sua família, mas sem que ensejasse a responsabilidade civil da plataforma, em nossa leitura.

Já em relação aos casos em que o Tribunal Superior do Trabalho julgou a hipótese dos danos oriundos de agressão física de um empregado por um colega de trabalho, reconheceu, quase que uniformemente, a responsabilidade civil do empregador, a partir do pressuposto geral de que é da alçada da empresa manter um meio ambiente de trabalho seguro e sadio, de sorte que deveria ter tomado todas as providências para que a agressão não ocorresse.

Há acórdão que imputa a responsabilidade civil pelo fato de a agressão caracterizar-se como acidente de trabalho previdenciário, baralhando as esferas jurídicas, além de ter-se dado dentro da empresa durante o expediente ${ }^{72}$, bem assim há decisão que responsabilizou a empregadora pela indenização por danos morais decorrente de uma surra que o autor recebeu de seu superior hierárquico dentro da van que os levava do trabalho para casa, cuja desavença começou ainda nas dependências da empresa ${ }^{73}$, sem que, nesses dois casos, as decisões tenham referido se as agressões foram cometidas no exercício do trabalho ou em razão dele (art. 932, III, in fine, do Código Civil), nem se, ao menos, foi precedida de ameaças de conhecimento prévio do empregador, como forma de que ele assumisse os riscos pela sua omissão em não ter intervido preventivamente (art. 927, parágrafo único, do Código Civil).

De forma abstrata e generalizante, outra decisão afirmou que: "Sendo incontroversa a ocorrência de agressão física contra o reclamante, no ambiente de trabalho, por parte de colega de trabalho, restam configurados os requisitos legais para a reparação vindicada nos autos, nos termos dos arts. 186, 927, 932, III e 933 do Código Civil e 5º, incisos V e X, da Constituição Federal."74

\footnotetext{
71 "Segue que, em nossa opinião, poderá o microssistema incidir nas relações de trabalho, na medida em que o empregador forneça o transporte para levar seus empregados de um lugar para outro, havendo cobrança de valores ou mesmo graciosamente, nesse último amoldar-se-á ao transporte gratuito com ganhos indiretos. São exemplos o transporte itinerário, de casa ao local de trabalho, o transporte de empregado que presta labor fora do estabelecimento empresarial, visitando clientes. Excluiu-se, de outra banda, da incidência normativa as relações em que os empregados são os motoristas dos veículos, pois aqui perde ele a condição de transportado, passando a ser agente de eventual dano." (MOLINA, André Araújo. Sistemas de responsabilidade civil objetiva e os acidentes de trabalho. Revista do TST, São Paulo, vol. 79, n. 2, p. 70/117, abr./jun. 2013).

72 TST - $2^{\mathrm{a}}$ Turma - AIRR n. 001101-47.2011.5.01.0030 - Rel. Min. José Roberto Freire Pimenta - DEJT 04.03.2016.

73 TST - $3^{a}$ Turma - AIRR n. 162300-16.2009.5.15.0109 - Rel. Min. Alexandre de Souza Agra Belmonte DEJT 02.10.2015.

${ }^{74}$ TST - $2^{\mathrm{a}}$ Turma - AIRR n. 010477-57.2016.5.03.0020 - Rel. ${ }^{a}$ Min. ${ }^{a}$ Delaíde Miranda Arantes - DEJT 04.10.2019.
} 
Ilustrativa da recorrente omissão da Corte quanto ao fato de a agressão ter origem ou não no exercício do trabalho ou em razão dele, outra decisão apontou os requisitos para os casos de agressão por colega de trabalho, sem colocar em evidência esse pressuposto específico:

\begin{abstract}
Os requisitos necessários para a configuração da responsabilidade civil do empregador são: dano, nexo causal e culpa empresarial, como regra. Já a responsabilidade civil do empregador, por ato praticado por empregado, foge à regra geral, porquanto prescinde de culpa para sua ocorrência, tratando-se, pois, de responsabilidade objetiva. Nesse sentido, os arts. 932, III, e 933 do CC. Na hipótese, infere-se do acórdão regional a presença dos requisitos necessários para a responsabilização civil da empregadora pelo ato praticado pelo empregado, quais sejam: a) prejuízo causado a terceiros - consistente na agressão física sofrida pelo Reclamante (à época menor aprendiz) provocada por empregado da Reclamada; b) o ato lesivo decorreu de dolo do empregado da empresa; c) existência de relação de emprego entre o causador do dano e a empresa Reclamada e, por fim, d) o fato lesivo ocorreu durante o horário de trabalho. Assim, configurada a responsabilidade objetiva da empregadora pelo ato de violência praticado por empregado seu, que agrediu fisicamente outro colega de trabalho, menor aprendiz, no local e horário de serviço. ${ }^{75}$
\end{abstract}

Os acórdãos destacados interpretam, com a devida vênia, os arts. 932, III, e 933 do Código Civil de forma incompleta, na medida em que consideram satisfeitos os seus requisitos pelo simples fato de o evento danoso ter ocorrido no local e horário de trabalho - aplicando o conceito de acidente previdenciário da Lei n. 8.213/1991 -, bem como o fato de que o agressor mantinha uma relação de emprego com a pessoa jurídica demandada, sendo um seu preposto de responsabilidade civil, de forma geral e abstrata, sem divisar se a conduta ofensiva efetiva foi praticada no exercício do trabalho que Ihe competia ou em razão dele, ainda que o seja em abuso da função desempenhada.

Precisamente nesse último ponto, do abuso no exercício da função, corretamente, o tribunal condenou um empregador pelos danos causados a dois trabalhadores por um terceiro empregado, motorista, que causou um acidente de trânsito ao perder a direção do veículo em que trabalhava, após a ingestão de bebida alcóolica ${ }^{76}$, bem como no caso em que um colega de trabalho, numa brincadeira envolvendo uma escavadeira da empresa, enquanto desempenhava as suas tarefas, terminou por causar a morte de outro trabalhador em um acidente ${ }^{77}$.

A parte a crítica neste ponto, ressalvamos que há decisão isolada do Tribunal que avançou na pesquisa da conexão das agressões com o exercício do trabalho, de modo que um acórdão concluiu que o empregador não era responsável pela morte do empregado, assassinado por colega de trabalho, na entrada do serviço, justamente por conta de que o estopim para a desavença foi uma conduta praticada fora do local de trabalho e que os supervisores não haviam

75 TST - 6 ${ }^{\text {a }}$ Turma - AIRR n. 284700-67.2010.5.03.0000 - Rel. Min. Mauricio Godinho Delgado - DEJT 23.09.2011.

76 TST - 3 $3^{\mathrm{a}}$ Turma - RR n. 084940-12.2007.5.10.0821 - Rel. Min. Alexandre de Souza Agra Belmonte - DEJT 22.11.2013.

77 TST - 4 ${ }^{\text {a }}$ Turma - RR n. 064200-50.2008.5.03.0091 - Rel. Min. Fernando Eizo Ono - DEJT 19.04.2011. 
tomado conhecimento da ameaça em tempo hábil a tomar providências, mesmo que o agressor fosse um empregado e que o fatídico evento tenha ocorrido em suas dependências. ${ }^{78}$

Esperamos que as próximas decisões da Corte avancem, como quer a parte final do art. 932, III, do Código Civil, na apuração das condições fáticas afirmadas no acórdão regional em torno da conduta lesiva ter sido praticada (ou não) no contexto do exercício do trabalho ou em razão dele, para estabelecer o dever de indenizar, mesmo que o evento, nesse último caso, atenda os pressupostos para a responsabilidade previdenciária do INSS, mais elástica.

Para que a jurisprudência do Tribunal Superior do Trabalho evolua no sentido das críticas apontadas, é indispensável que os juízes de primeiro grau explorem as particularidades fáticas dos casos concretos durante a instrução do feito, bem como que sejam objeto de análise e constem expressamente dos acórdãos regionais, para permitir que a Corte Superior faça o adequado enquadramento, superando a barreira da Súmula n. 126 do TST.

\section{CONCLUSÕES}

A premissa da nossa posição é que o intérprete não deve confundir as esferas previdenciária e de responsabilidade civil, na medida em que os seus objetivos, requisitos e as consequências são muito diferentes nestes citados compartimentos do ordenamento jurídico.

Logo, a depender dos dados fáticos do caso concreto, a agressão física sofrida pelo trabalhador poderá resultar apenas no enquadramento previdenciário a cargo do INSS, somente na responsabilidade civil do empregador ou, inclusive, simultaneamente, despertar ambas as consequências, estando presentes os seus independentes pressupostos.

Na perspectiva previdenciária, o art. 21 , II, da Lei n. 8.213/1991, considera como acidente de trabalho por equiparação $o$ ato de agressão ou ofensa física intencional praticados por terceiro ou companheiros de trabalho, no local e horário de trabalho, inclusive os cometidos por pessoa privada do uso da razão, desde que o evento traga como consequência lesão corporal ou perturbação funcional que cause a perda ou a redução da capacidade para o trabalho por período superior a 15 dias, mesmo que o ato seja cometido nos períodos destinados à refeição, descanso ou outras necessidades fisiológicas, no local do trabalho ou durante este.

Já na esfera da responsabilidade civil, a agressão física, quando cometida por um terceiro, estranho à relação de trabalho, deve convocar o jurista para avaliar se a probabilidade de a sofrer se insere nos riscos naturais daquela atividade específica, quando o empregador, por exceção, seria responsável, amoldando-se à essa hipótese as agressões premeditadas em que a vítima alertou o empregador dos riscos concretos criados.

78 TST - $7^{\text {a }}$ Turma - AIRR-Ag n. 044785-41.2009.5.12.0012 - Rel. Min. Pedro Paulo Manus - DEJT 12.04.2013. 
Quando a agressão é praticada por um colega de trabalho, em regra, o empregador responderá objetivamente pelo ato do empregado ou preposto, desde que o ato lesivo tenha sido praticado no exercício do trabalho que lhe competia ou em razão dele, mesmo que em abuso da função, colocando uma linha divisória no sentido de que não haverá responsabilidade civil do empregador, apenas do causador direto, quando o ato lesivo praticado pelo preposto não guardar relação com o trabalho, ainda que seja praticado dentro do local e no horário de trabalho.

A jurisprudência do Tribunal Superior do Trabalho, em todas essas nuances, ainda é bastante vacilante, principalmente misturando as esferas previdenciária e a responsabilidade civil, bem como confundindo a responsabilidade objetiva pelo risco da atividade com a extrema hipótese do risco integral, havendo, por isso, grande espaço para avançar e uniformizar.

\section{REFERÊNCIAS}

ALVIM, Agostinho. Da inexecução das obrigações e suas consequências. 4 ed. São Paulo: Saraiva, 1972.

BRANDÃO, Cláudio. Acidente do trabalho e responsabilidade civil do empregador. São Paulo: LTr, 2006.

CAIRO JÚNIOR, José. O acidente do trabalho e a responsabilidade civil do empregador. 8 ed. São Paulo: LTr, 2015.

FARIAS, Cristiano Chaves de; ROSENVALD, Nelson; BRAGA NETTO, Felipe Peixoto. Curso de Direito Civil. Responsabilidade Civil. 4 ed. Salvador: Juspodivm, 2017, vol. 3.

FRAZÃO, Ana. Risco da empresa e responsabilidade por acidentes de trabalho. Revista $L T r$, São Paulo, vol. 80, n. 10, p. 1179-1193, out. 2016.

GAGLIANO, Pablo Stolze; PAMPLONA FILHO Rodolfo. Novo Curso de Direito Civil. Responsabilidade civil. 3 ed. São Paulo: Saraiva, 2005.

GARCIA, Gustavo Filipe Barbosa. Acidentes de trabalho. 4 ed. São Paulo: Método, 2011.

GRAMSTRUP, Erick Frederico. Responsabilidade objetiva na cláusula geral codificada e nos micro-sistemas. In: DELGADO, Mário Luiz; ALVES, Jônes Figueiredo (coord.). Novo Código Civil. Questões Controvertidas. Responsabilidade Civil. São Paulo: Método, 2006.

GONÇALVES, Carlos Roberto. Responsabilidade Civil. 8 ed. São Paulo: Saraiva, 2003.

JAYME, Erik. Identité culturelle et intégration: le droit international privê postmoderne. Recueil des Cours, Académie de Droit Internacional de la Haye, v. 251 (1995).

JESUS, Damásio E. de. Direito Penal. 23 ed. São Paulo: Saraiva, 1999, vol. 1.

MARANHÃO, Ney. Responsabilidade civil objetiva pelo risco da atividade: uma perspectiva civilconstitucional. São Paulo: Método, 2010.

MARQUES, Cláudia Lima. Superação das antinomias pelo diálogo das fontes: o modelo brasileiro de coexistência entre o Código de Defesa do Consumidor e o Código Civil de 2002. Revista de Direito do Consumidor, São Paulo, vol. 51, p. 34-67, set. 2004.

MELO, Raimundo Simão de. Ações acidentárias na Justiça do Trabalho. São Paulo: LTr, 2011. 
MIRAGEM, Bruno. Direito Civil. Responsabilidade Civil. São Paulo: Saraiva, 2015.

MIRANDA, Francisco Cavalcante Pontes de. Tratado de Direito Privado. Campinas: Bookseller, Tomo I, 1999.

MOLINA, André Araújo. Sistemas de responsabilidade civil objetiva e os acidentes de trabalho. Revista do TST, São Paulo, vol. 79, n. 2, p. 70/117, abr./jun. 2013.

MOLINA, André Araújo. O nexo causal nos acidentes de trabalho. Revista LTr, São Paulo, ano 76, n. 12, p. 1421-1432, dez. 2012.

NORONHA, Fernando. O nexo de causalidade na responsabilidade civil. Revista dos Tribunais, São Paulo, ano 92, vol. 816, p. 733-752, outubro 2003.

NORONHA, Fernando. Responsabilidade civil: uma tentativa de ressistematização. Revista de Direito Civil, São Paulo, ano 17, n. 64, p. 12-47, abr.-jun. 1993.

OLIVEIRA, Sebastião Geraldo de. Indenizações por acidente do trabalho ou doença ocupacional. 10 ed. São Paulo: LTr, 2018.

PEREIRA DE CASTRO; Carlos Alberto; LAZZARI, João Batista. Manual de direito previdenciário. 23 ed. Rio de Janeiro: Forense, 2020.

REALE, Miguel. Lições preliminares de direito. 27 ed. São Paulo: Saraiva, 2007.

SCHREIBER, Anderson. Novos paradigmas da responsabilidade civil: da erosão dos filtros da reparação à diluição dos danos. 5 ed. São Paulo: Atlas, 2013.

TEPEDINO, Gustavo. Notas sobre o nexo de causalidade. Revista Jurídica, ano 50, n. 296, p. 718, junho 2002.

THEODORO JÚNIOR, Humberto. A responsabilidade civil na nova Constituição brasileira. Revista Jurídica, Porto Alegre, v. 168, p. 127-137, out. 1991.

VEIGA, Aloysio Corrêa da. Responsabilidade civil no transporte de passageiros: "assalto a ônibus e excludentes”. Revista do TST, Brasília, vol. 79, n. 2, p. 42-52, abr./jun. 2013.

VENOSA, Sílvio de Salvo. Direito Civil. Responsabilidade Civil. 3 ed. São Paulo: Atlas, 2003, v. 4.

Recebido: 14.01 .2022

Aprovado: 01.03.2022

Como citar: MOLINA, André Araújo. A responsabilidade civil do empregador nos casos de agressão física sofrida pelo trabalhador. Revista IBERC, Belo Horizonte, v. 5, n. 1, p. 78-111, jan./abr. 2022.

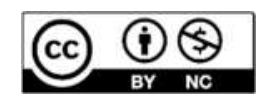

